\title{
Article
}

\section{The Trace Element Selenium Is Important for Redox Signaling in Phorbol Ester-Differentiated THP-1 Macrophages}

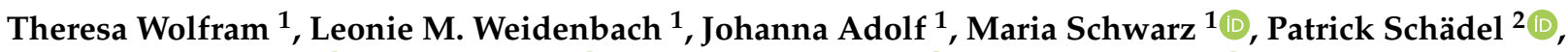

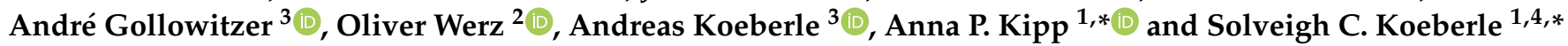 \\ 1 Department of Nutritional Physiology, Institute of Nutritional Sciences, Friedrich Schiller University Jena, \\ 07743 Jena, Germany; theresa.wolfram@uni-jena.de (T.W.); leonie.weidenbach@uni-jena.de (L.M.W.); \\ johanna232@gmx.net (J.A.); schwarz.maria@uni-jena.de (M.S.) \\ 2 Department of Pharmaceutical/Medicinal Chemistry, Institute of Pharmacy, University of Jena, \\ 07743 Jena, Germany; patrick.schaedel@uni-jena.de (P.S.); oliver.werz@uni-jena.de (O.W.) \\ 3 Michael Popp Institute and Center for Molecular Biosciences Innsbruck (CMBI), University of Innsbruck, \\ 6020 Innsbruck, Austria; andre.gollowitzer@uibk.ac.at (A.G.); andreas.koeberle@uibk.ac.at (A.K.) \\ 4 Institute of Pharmacy/Pharmacognosy and Center for Molecular Biosciences Innsbruck (CMBI), University of \\ Innsbruck, Innrain 80-82, 6020 Innsbruck, Austria \\ * Correspondence: anna.kipp@uni-jena.de (A.P.K.); solveigh.koeberle@uibk.ac.at (S.C.K.); \\ Tel.: +49-3641-9-49609 (A.P.K.); +43-512-507-58404 (S.C.K.)
}

Citation: Wolfram, T.; Weidenbach, L.M.; Adolf, J.; Schwarz, M.; Schädel, P.; Gollowitzer, A.; Werz, O.; Koeberle, A.; Kipp, A.P.; Koeberle, S.C. The Trace Element Selenium Is Important for Redox Signaling in Phorbol Ester-Differentiated THP-1 Macrophages. Int. J. Mol. Sci. 2021, 22, 11060. https://doi.org/10.3390/ ijms222011060

Academic Editors: Petra A. Tsuji and Dolph L. Hatfield

Received: 14 September 2021

Accepted: 11 October 2021

Published: 14 October 2021

Publisher's Note: MDPI stays neutra with regard to jurisdictional claims in published maps and institutional affiliations.

Copyright: (c) 2021 by the authors. Licensee MDPI, Basel, Switzerland. This article is an open access article distributed under the terms and conditions of the Creative Commons Attribution (CC BY) license (https:// creativecommons.org/licenses/by/ $4.0 /)$
Abstract: Physiological selenium (Se) levels counteract excessive inflammation, with selenoproteins shaping the immunoregulatory cytokine and lipid mediator profile. How exactly differentiation of monocytes into macrophages influences the expression of the selenoproteome in concert with the Se supply remains obscure. THP-1 monocytes were differentiated with phorbol 12-myristate 13-acetate (PMA) into macrophages and (i) the expression of selenoproteins, (ii) differentiation markers, (iii) the activity of NF- $\mathrm{KB}$ and NRF2, as well as (iv) lipid mediator profiles were analyzed. Se and differentiation affected the expression of selenoproteins in a heterogeneous manner. GPX4 expression was substantially decreased during differentiation, whereas GPX1 was not affected. Moreover, Se increased the expression of selenoproteins $\mathrm{H}$ and $\mathrm{F}$, which was further enhanced by differentiation for selenoprotein $\mathrm{F}$ and diminished for selenoprotein H. Notably, LPS-induced expression of NF- $\mathrm{k}$ target genes was facilitated by $\mathrm{Se}$, as was the release of COX- and LOX-derived lipid mediators and substrates required for lipid mediator biosynthesis. This included $\mathrm{TXB}_{2}, \mathrm{TXB}_{3}, 15-\mathrm{HETE}$, and 12-HEPE, as well as arachidonic acid (AA), eicosapentaenoic acid (EPA), and docosahexaenoic acid (DHA). Our results indicate that Se enables macrophages to accurately adjust redox-dependent signaling and thereby modulate downstream lipid mediator profiles.

Keywords: selenium; selenoprotein; macrophage; differentiation; inflammation; redox signaling; NRF2; NF-kB; lipid mediators

\section{Introduction}

Selenium (Se) is an essential trace element that is important for human health. It is required for various physiological processes including immune function and mammalian development, as well as thyroid hormone metabolism, and Se deficiency has been implicated in various pathologies including inflammation, heart disease, and cancer $[1,2]$. The biological effects of Se are mainly mediated by selenoproteins, which contain the amino acid selenocysteine, the Se-containing analogue of cysteine, in their polypeptide chain [2]. Most commonly, selenocysteine is part of the catalytic center and provides the selenoproteins with unique chemical activities due to the superior reactivity of selenocysteine. Accordingly, many selenoproteins regulate redox-dependent processes [3] and adequate levels of Se and selenoproteins have been reported to be critical for proliferation, differentiation, and inflammatory processes [4]. The impact of individual selenoproteins is thereby dependent on the cell type and differentiation state. Hence, expression levels 
of selenoproteins largely differ between undifferentiated and differentiated cells, which suggests that distinct selenoproteins inherit specific functions depending on the differentiation state. Knock-down of selenoprotein (SELENO)H, for example, triggers proliferation of undifferentiated human HT-29 colorectal carcinoma cells and decreases their differentiation, while SELENOH is significantly downregulated in differentiated HT-29 cells [5]. In contrast, thioredoxin reductases (TXNRDs) are upregulated in differentiated adiopocytes and inhibit the differentiation process [6,7]. Moreover, various other selenoproteins, such as glutathione peroxidases (GPXs), SELENOO, and SELENOK, have been shown to be implicated in proliferation and differentiation of distinct cell types $[4,8,9]$.

Macrophages, which are derived from circulating monocytes, are important cells of the innate immune system [10]. Depending on the microenvironmental signals, macrophages give rise to a variety of different tissue-resident-activated macrophage sub-populations, including pro-inflammatory M1- or anti-inflammatory M2-type macrophages [11,12]. Two redox-regulated transcription factors, nuclear factor $\kappa$-light-chain-enhancer (NF- $\mathrm{kB}$ ) and nuclear factor erythroid 2-related factor 2 (NRF2), are key regulators of inflammation and oxidative stress-induced cellular responses in macrophages. These play pivotal roles in host defense and inflammatory processes but are also important for tissue homeostasis and repair $[13,14]$. While NF- $\mathrm{kB}$ mainly triggers gene expression of inflammatory proteins like cyclooxygenase (COX)2 and tumor necrosis factor (TNF) $\alpha$, thereby enhancing oxidative stress, NRF2 activates the antioxidant response, which includes the upregulation of TXNRD1, GPX4, superoxide dismutase (SOD)1, heme oxygenase (HMOX)1, and catalase (CAT), as well as proteins involved in glutathione (GSH) homeostasis, including solute carrier family 7 member 11 (SLC7A11), glutamate-cysteine ligase catalytic subunit (GCLC), and glutamate-cysteine ligase modifier subunit (GCLM). The two pathways are crosslinked by a complex network, thereby allowing fine-tuned inflammatory responses and preventing exacerbated oxidative stress and inflammation [15]. Various studies suggest that adequate Se levels limit excessive inflammation [2], and genetic inhibition studies identified specific functions of individual selenoproteins in the macrophage maturation process (GPX1 and SELENOP), as well as in the limitation of the oxidative burst (SELENOK) [16].

In mammals, the hierarchy of selenoproteins ensures that indispensable selenoproteins are expressed at the expense of less important ones when the Se supply is limited [17]. A second hierarchical principle ensures the transport of Se to privileged tissues, e.g., the brain. The expression pattern of selenoproteins is highly dynamic, tightly regulated, and finetuned depending on the developmental stage, physiological conditions, and the availability of Se $[1,18,19]$.

Given that adequate expression of selenoproteins (i) depends on Se supply, (ii) varies widely between different tissue types, (iii) can be altered by the differentiation process, and (iv) is required for an appropriate inflammatory response, this raises the questions of how the Se status affects monocyte/macrophage function and how selenoprotein expression levels are regulated in macrophages during the differentiation process. Human THP-1 monocytes have been suggested to be a valuable model for macrophage differentiation because phorbol 12-myristate 13-acetate (PMA)-differentiated THP-1 macrophages resemble the native monocyte-derived macrophages with regard to (i) morphology, (ii) expression of membrane antigens and receptors, (iii) the release of secretory factors, and (iv) transient induction of proto-oncogenes [20]. We established a THP-1 model to investigate the effect of Se on (i) cell proliferation and differentiation of monocytes and (ii) the expression of selenoproteins in undifferentiated monocytes as compared to differentiated macrophages, as well as (iii) the inflammatory response upon lipopolysaccharide (LPS) stimulation. Interestingly, Se treatment neither significantly affected the proliferation of human THP-1 monocytes nor the differentiation process itself. However, expression of almost all selenoproteins was modulated by the differentiation state of THP- 1 cells. Adequate levels of Se were moreover important for the LPS-induced inflammatory response, resulting in an upregulation of NF- $\mathrm{KB}$ target gene expression as well as increased biosynthesis of lipid mediators (LMs). In conclusion, the tight regulation of the selenoproteome by both Se and differentiation 
processes together with the dependency of the inflammatory response on Se levels strongly suggest that an adequate Se status is indispensable for proper functioning of macrophages.

\section{Results}

\subsection{Se Does Not Affect Differentiation of THP-1 Cells into Macrophages}

To investigate the effect of Se on the differentiation process of human THP-1 leukemic monocytes into macrophages, we initially determined the Se concentration and incubation time required for adequate expression of Se-sensitive selenoproteins. Concentrationdependent studies with $0-500 \mathrm{nM}$ sodium selenite for $72 \mathrm{~h}$ confirmed a significant upregulation of the protein expression levels of the Se-sensitive selenoproteins GPX1 and SELENOH (Figure S1a,b), while expression of TXNRD1 was not affected (Figure S1c). Moreover, protein expression of GPX1, SELENOH, and TXNRD1 was time-dependently upregulated, reaching a maximum after $72 \mathrm{~h}$ (Figure S1d-f). Cell number was not significantly affected up to $72 \mathrm{~h}$ by $50 \mathrm{nM}$ Se treatment (Figure S1g). Pre-treatment with $50 \mathrm{nM}$ Se for $72 \mathrm{~h}$ was therefore used for subsequent experiments.

THP-1 differentiation into macrophages can be induced by PMA and is associated with increased cell size and adherence [21,22]. Concentration-response studies (0-100 nM PMA) showed that treatment with low (5 $\mathrm{nM}$ ) PMA concentrations for $48 \mathrm{~h}$ was not sufficient to induce complete differentiation, as indicated by loosely attached cells with monocytic morphology (Figure S1h). Incubation with $25 \mathrm{nM}$ for $48 \mathrm{~h}$ induced a pronounced adherence of the cells, with significantly increased cell sizes (Figure S1h). Higher concentrations of PMA (100 nM) did not further increase adherence or cell size. Recent studies indicate that high PMA concentrations induce a rather pro-inflammatory type of macrophage which is less responsive towards stimuli [22,23]. Hence, $25 \mathrm{nM}$ of PMA was used for differentiation. In addition, the cell cycle inhibitor p21WAF1/Cip1 was induced by PMA reaching a maximum at $25 \mathrm{nM}$ PMA (Figure 1a). This effect was independent of Se treatment. Time-dependent studies $(2-72 \mathrm{~h})$ with $25 \mathrm{nM}$ PMA confirmed a progressive increase in relative cell adherence, reaching a maximum after $48 \mathrm{~h}$ (Figure 1b). To further explore the influence of Se on the PMA-induced THP-1 differentiation process, cellular autofluorescence and granularity, as well as extracellular CD68 levels, were analyzed. All three differentiation markers increased with PMA treatment, whereas Se did not significantly affect differentiation (Figure 1c-e). In summary, differentiation of monocytes into macrophages was not significantly affected by the Se status of the cells. 

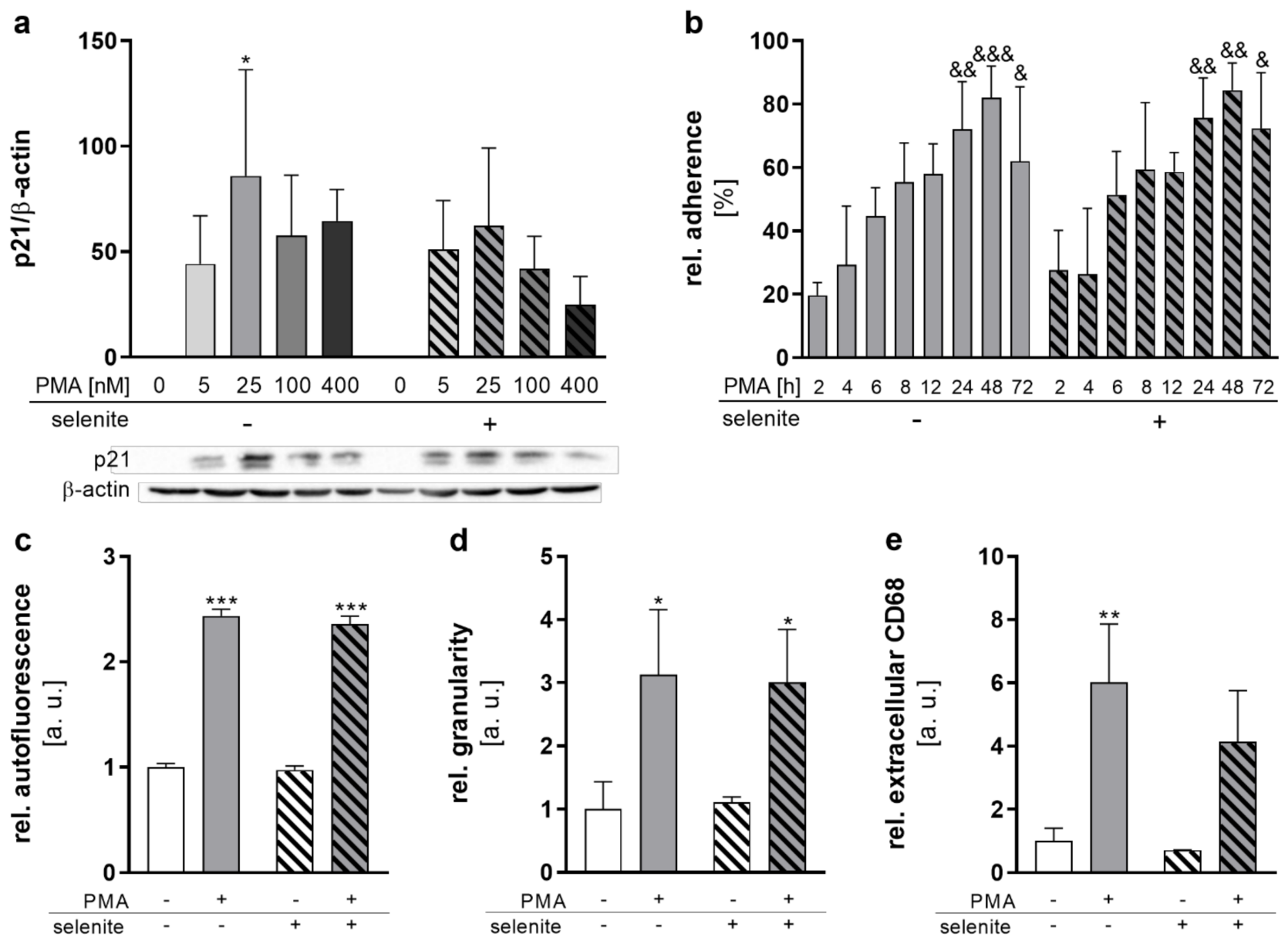

Figure 1. Selenium does not affect differentiation. THP-1 monocytes were pre-treated for $72 \mathrm{~h}$ with or without $50 \mathrm{nM}$ sodium selenite (selenite) and differentiated into macrophages by $25 \mathrm{nM}$ PMA or the indicated concentration with or without $50 \mathrm{nM}$ selenite for the indicated time points (b) or for $48 \mathrm{~h}(\mathbf{a}, \mathbf{c}-\mathbf{e})$. (a) Protein expression of p21 was normalized to $\beta$-actin. -PMA/-selenite samples were set to 1. A representative blot is shown. (b) The relative adherence was calculated as (number of adherent cells/total number of cells) $\times 100$. (c-e) The autofluorescence (c), intracellular granularity (d), and extracellular CD68 (e) were determined using flow cytometry. Data are given as means + SD ( $n=3-4)$. Two-way ANOVA with Bonferroni's post-test. Significant outliers were determined by Grubbs' test $(\alpha=0.05)$. $p<0.05,{ }^{* *} p<0.01,{ }^{* * *} p<0.001$ vs. cells without PMA (PMA effect); \& $p<0.05, \& \& p<0.01$, \&\&\& $p<0.001$ vs. 2 h PMA.

\subsection{PMA-Induced Differentiation of Monocytes to Macrophages Alters the Selenoprotein Expression Profile}

To investigate whether selenoprotein expression is affected by differentiation in combination with varying Se supply, we analyzed the protein levels of selenoproteins under Se-deficient, as well as Se-adequate, conditions at increasing PMA concentrations. As expected, selenoprotein expression was upregulated in Se-treated cells, as shown for GPX4, SELENOH, SELENOS, and SELENOF (Figure 2a-d). Most pronounced Se-dependent effects were obtained for SELENOF in undifferentiated THP-1 monocytes with a 12-fold upregulation, followed by SELENOS and SELENOH. GPX4 expression was only moderately affected, being upregulated by 1.8-fold in Se-treated cells. In contrast, PMA substantially reduced expression levels of the selenoproteins SELENOH, SELENOS, and GPX4 in both Se-treated as well as untreated cells (Figure $2 \mathrm{a}-\mathrm{c}$ ). However, the protein expression of SELENOF increased upon PMA-induced differentiation (Figure 2d), while other selenoproteins, such as GPX1, SELENOO, TXNRD1, and TXNRD2, were almost unaffected by PMA-induced differentiation (Figure S2a-d). Accordingly, total activities of the TXNRD and GPX selenoprotein families were also not modulated by PMA (Figure S2e,f). 

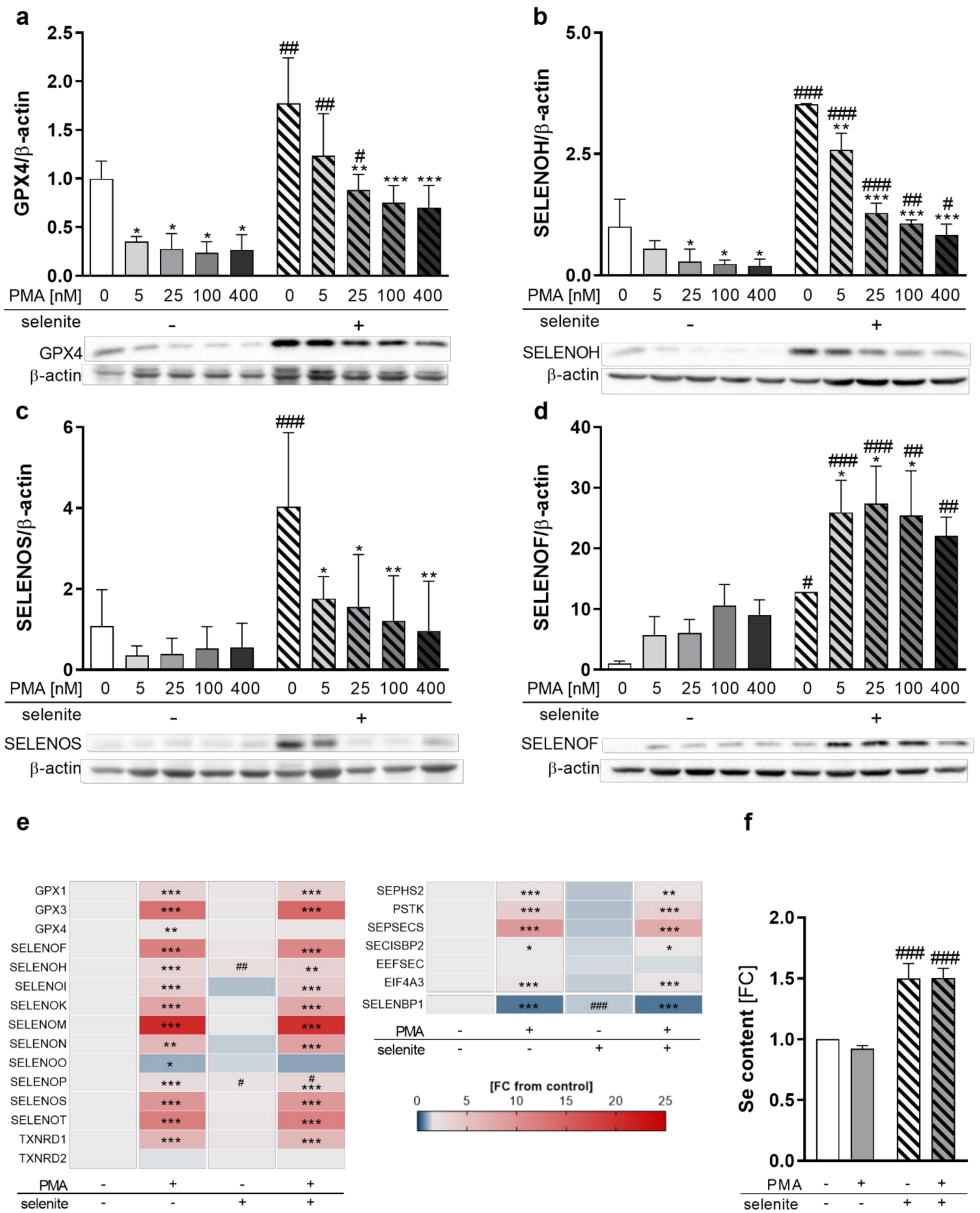

Figure 2. Expression of selenoproteins as well as proteins involved in selenoprotein biosynthesis during differentiation. THP-1 monocytes were pre-treated for $72 \mathrm{~h}$ with or without $50 \mathrm{nM}$ sodium selenite (selenite) and differentiated into macrophages using 5-400 nM PMA (a-d) or $25 \mathrm{nM}$ PMA (e,f) with or without $50 \mathrm{nM}$ sodium selenite treatment for $48 \mathrm{~h}$. (a-d) Protein expressions of GPX4 (a), SELENOH (b), SELENOS (c), and SELENOF (d) were normalized to $\beta$-actin. -PMA/selenite samples were set to 1 . Representative blots are shown. (e) Heatmap of mRNA expression of different selenoproteins and proteins involved in the biosynthesis of selenoproteins analyzed by qRT-PCR. The color scale indicates the mean difference as fold change (FC) of target genes vs. -PMA/-selenite $(F C=1)$. (f) Se content of the cells. -PMA/-selenite samples were set to 1 . Data are given as means + SD $(n=3-4)$. Two-way ANOVA with Bonferroni's post-test. Significant outliers were determined by Grubbs' test $(\alpha=0.05) .{ }^{*} p<0.05,{ }^{* *} p<0.01,{ }^{* * *} p<0.001$ vs. cells without PMA (PMA effect); \# $p<0.05,{ }^{\# \#} p<0.01,{ }^{\# \#} p<0.001$ vs. cells without selenite (Se effect). 
As changes in selenoprotein expression upon PMA treatment can be regulated at either the transcriptional or translational levels, we investigated mRNA levels of the selenoproteins in untreated and PMA-differentiated THP-1 cells. Interestingly, mRNA levels were not related to protein expression. The only selenoprotein which was downregulated by PMA on mRNA level was SELENOO (Figure 2e). Significant upregulation of mRNA levels was observed for all other selenoproteins investigated, with SELENOM showing the strongest effect with a 20-fold increase in macrophages as compared to monocytes (Figure 2e). Moreover, mRNA levels of Se-binding protein 1 (SELENBP1), a non-selenocysteine-containing protein that covalently binds Se [24,25], were downregulated by PMA (Figure 2e), which was also observed upon differentiation of other cell types [26,27].

Based on this discrepancy between mRNA and protein expression of selenoproteins, the mRNA levels of proteins involved in selenoprotein synthesis were analyzed. While expression of genes responsible for the biosynthesis of selenocysteine at the t-RNA ${ }^{[\mathrm{Ser}] \mathrm{Sec}}$ (e.g., selenophosphate synthetase 2 (SEPHS2), phosphoseryl-tRNA kinase (PSTK), sep (o-phosphoserine) tRNA:sec (selenocysteine) tRNA synthase (SEPSECS)) were significantly upregulated, mRNA expression of proteins involved in selenoprotein translation (SECIS binding protein 2 (SECISBP2) and eukaryotic elongation factor, selenocysteine-tRNA specific (EEFSEC)) were less affected by PMA treatment (Figure 2e). Interestingly, eukaryotic translation initiation factor 4A3 (EIF4A3), which inhibits the biosynthesis of Se-sensitive selenoproteins, was significantly upregulated by PMA (Figure 2e). Moreover, cellular Se levels were independent from the differentiation state and upregulated by Se treatment by 1.5-fold in undifferentiated and differentiated cells, which excludes the possibility that Se availability limited protein expression of selenoproteins in PMA-treated cells (Figure 2f). In conclusion, PMA-induced differentiation downregulated selenoprotein expression of GPX4, SELENOH, and SELENOS but upregulated SELENOF, indicating differentiation-induced shifts of the selenoproteome.

\subsection{PMA and Se Treatment Modulate the Cellular Redox Status and the Activity of the Redox-Sensitive Transcription Factors NRF2 and NF- $k B$}

Based on the observed changes in selenoprotein expression induced by PMA differentiation together with the well-known impact of many selenoproteins on the regulation of the cellular redox homeostasis $[18,19]$, we wondered whether Se treatment affects the redox status in PMA-differentiated THP-1 macrophages. Surprisingly, total GSH levels decreased from PMA-induced differentiation independent of the Se status (Figure 3a). NRF2 and NF-KB are two transcription factors which are well-known to be regulated in a redox-dependent manner and to activate gene expression of antioxidant and inflammatory proteins, respectively [28]. The activity of $\mathrm{NAD}(\mathrm{P}) \mathrm{H}$ quinone oxidoreductase 1 (NQO1), a NRF2 target gene, was significantly upregulated in differentiated compared to undifferentiated cells (Figure $3 b$ ), which hints towards a putative activation of the transcription factor NRF2 in differentiated cells. To induce inflammatory conditions and activate the NF- $\mathrm{KB}$ signaling pathway, we included LPS stimulation for further experiments. NF- $\kappa B$ activation was studied by nuclear translocation of the subunit p65. In macrophages, NF- $\mathrm{KB}$ was activated by LPS stimulation in Se-treated but not in Se-deficient cells (Figure 3c). The mRNA expression of the NF- $\mathrm{KB}$ target genes COX2 and TNF $\alpha$ was increased by PMAinduced differentiation and further enhanced in LPS-stimulated THP-1 macrophages, with more pronounced effects under Se treatment (Figure 3d). Se effects were present in neither the release of TNF $\alpha$ nor COX2 protein levels (Figures 3e and S3a). Moreover, proteins that are involved in the biosynthesis of prostaglandins (e.g., prostaglandin E synthase (PGES) and thromboxane (TX)A synthase 1 (TXAS1)), as well as leukotriens and resolvins (arachidonate 5-lipoxygenase (ALOX5) and arachidonate 15-lipoxygenase (ALOX15)), were upregulated by PMA but not affected by Se (Figure 3d). Interestingly, ALOX5 mRNA expression was significantly upregulated in undifferentiated THP-1 cells and downregulated in the differentiated cells by LPS. Otherwise, LPS did not significantly affect the protein expression of the two selenoproteins GPX4 and SELENOF (Figure S3c,d). 
a

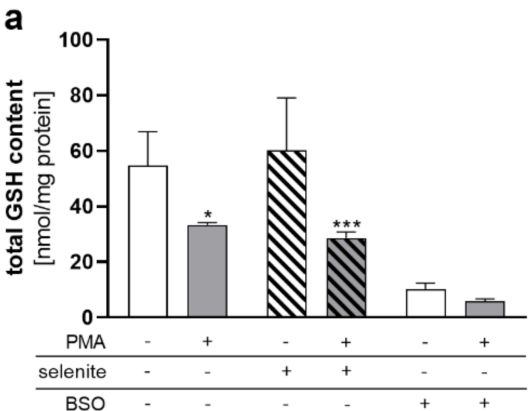

d

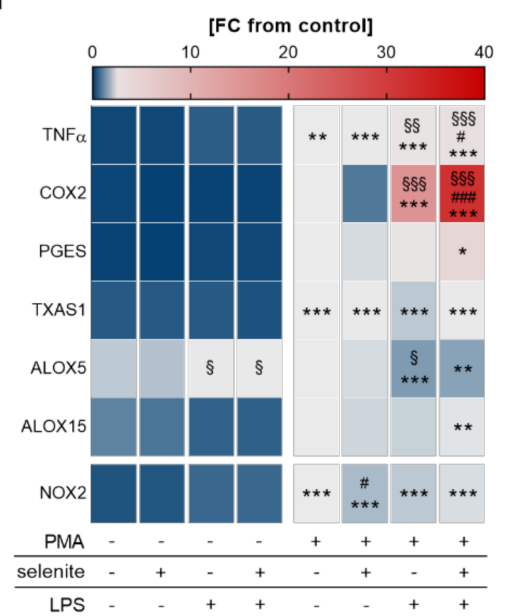

g

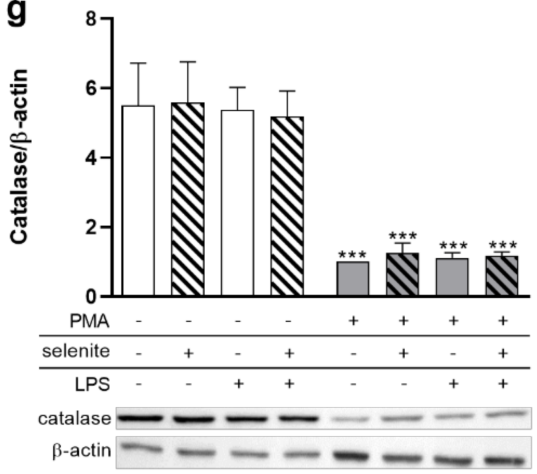

b

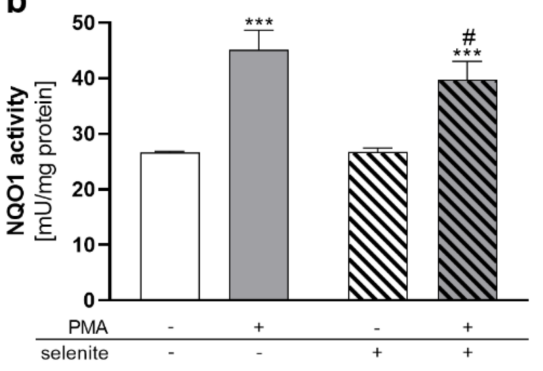

e

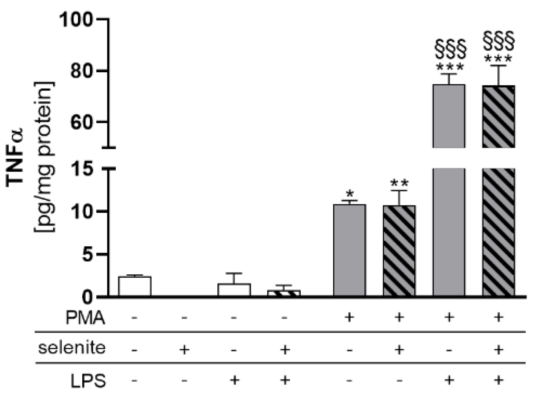

h

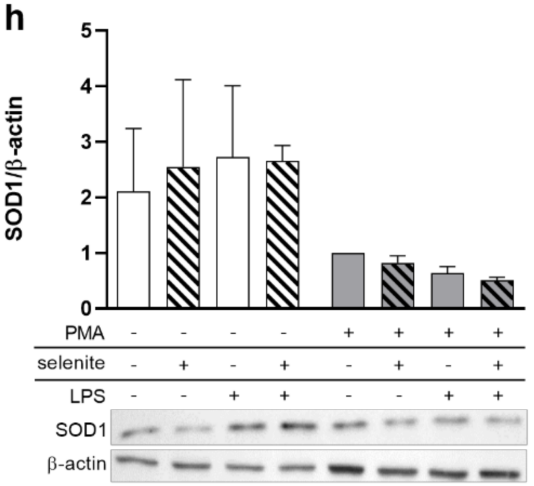

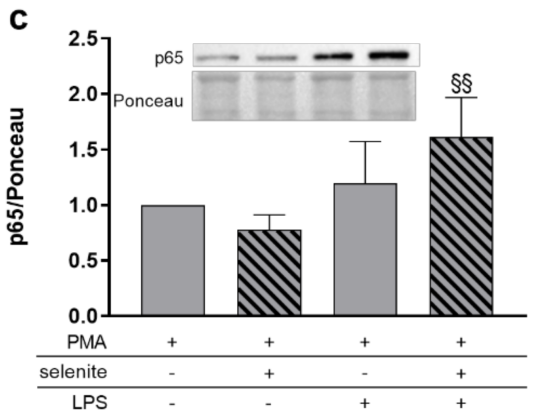

f

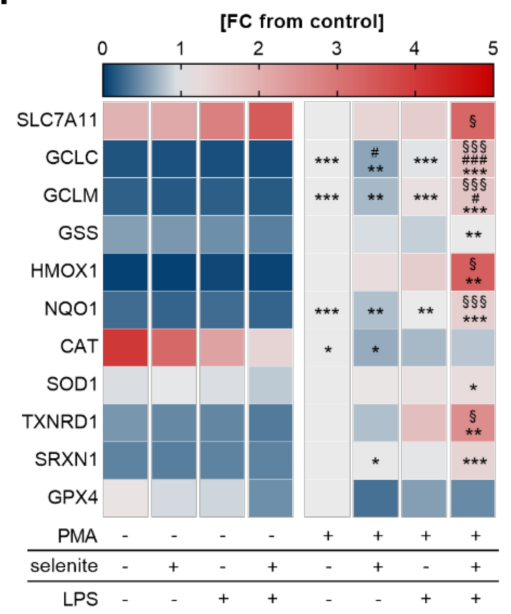

i

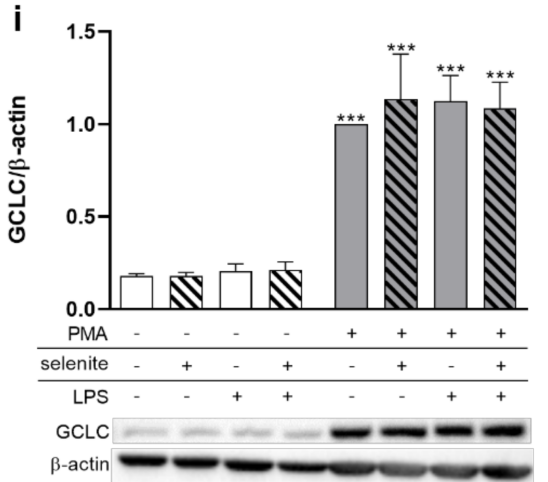

Figure 3. Redox-dependent regulation of NF- $\mathrm{kB}$ and NRF2 target gene transcription in THP-1 monocytes and macrophages. THP-1 monocytes were pre-treated with or without $50 \mathrm{nM}$ sodium selenite (selenite) for $72 \mathrm{~h}$ and differentiated into macrophages with $25 \mathrm{nM}$ PMA with or without $50 \mathrm{nM}$ selenite treatment for $48 \mathrm{~h}$. Cells were stimulated with $1 \mu \mathrm{g} / \mathrm{mL}$ lipopolysaccharide (LPS) (c-i) for $1 \mathrm{~h} \mathrm{(c),} 6 \mathrm{~h}(\mathbf{d}, \mathbf{f})$, or $24 \mathrm{~h}(\mathbf{e}, \mathbf{g}-\mathbf{i})$. (a) Total GSH content. The GSH synthesis inhibitor buthionine-sulfoximine $(0.25 \mathrm{mM}, \mathrm{BSO})$ was used as positive control. (b) NQO1 activity. (c) The protein expression of nuclear p65 was normalized to Ponceau staining. The -selenite/-LPS sample was set to 1. (d) Heatmap of mRNA expression of NF- $\mathrm{KB}$ target genes and enzymes involved in the LM biosynthesis investigated by qRT-PCR. mRNA expression of genes is given as fold change $(\mathrm{FC})$ vs. +PMA/-selenite/-LPS $(\mathrm{FC}=1)$. The color scale indicates the mean difference as the FC of target genes vs. +PMA/-selenite/-LPS (FC = 1). (e) TNF $\alpha$ release was analyzed by ELISA. (f) Heatmap of mRNA expression of NRF2 target genes investigated by qRT-PCR. mRNA expression of genes is given as fold change (FC) vs. +PMA/-selenite/LPS (FC = 1). The color scale indicates the mean difference as the FC of target genes vs. +PMA/-selenite/-LPS (FC = 1). (g-i) The protein expressions of CAT (g), SOD1 (h), and GCLC (i) were normalized to $\beta$-actin. The +PMA/-selenite/-LPS samples were set to 1 . The data of $(\mathbf{a}-\mathbf{c}, \mathbf{e}, \mathbf{g}-\mathbf{i})$ are given as means $+\mathrm{SD}(\mathrm{n}=3-4)$. Two-way ANOVA $(\mathbf{a}-\mathbf{c})$ or three-way ANOVA (d-i) with Bonferroni's post-test. Significant outliers were determined by Grubbs' test $(\alpha=0.05) .{ }^{*} p<0.05$, ${ }^{* *} p<0.01$, ${ }^{* * *} p<0.001$ vs. cells without PMA (PMA effect); ${ }^{\#} p<0.05$, \#\#\# $p<0.001$ vs. cells without selenite (Se effect); $\S p<0.05, \$ \S p<0.01, \S \S \S p<0.001$ vs. cells without LPS (LPS effect). 
For mRNA levels, PMA treatment upregulated most NRF2 target genes (GCLC, GCLM, glutathione synthetase (GSS), HMOX1, NQO1, SOD1, TXNRD1, SRXN1) with the exception of SLC7A11, CAT, and GPX4 (Figure 3f). The strong PMA-dependent downregulation of SLC7A11, a subunit of the cystine/glutamate antiporter system $X_{c}{ }^{-}$that is essential for the intracellular supply with cysteine and subsequent GSH biosynthesis, might explain the decreased levels of GSH in the PMA-differentiated cells, although mRNA levels of the proteins of GSH biosynthesis (GCLC, GCLM, GSS) were upregulated. Notably, Se treatment makes THP-1 macrophages more responsive to LPS-induced NRF2 gene expression, with up to threefold higher mRNA levels of NRF2 target gene expression (e.g., HMOX1) under Se-treated conditions as compared to Se-deficient conditions. Protein expressions of NRF2 target proteins CAT, SOD1, and GCLC were not affected by LPS stimulation and Se treatment (Figure 3g-i). However, CAT expression was significantly downregulated and GCLC was upregulated by PMA, whereas no pronounced PMA effects were observed on SOD1 expression (Figure 3g-i).

\subsection{Effects of LPS Treatment on LM profiles in THP-1 Monocytes and Macrophages}

Given that Se-treated PMA-differentiated macrophages were more responsive to LPSinduced NF- $\mathrm{KB}$ activation, we speculated that an adequate Se status might also affect LM biosynthesis. A metabolipidomics approach was employed to investigate the impact of Se on LPS-induced changes on the LM profile. Similar to what we observed for mRNA expression of COX2 and TNF $\alpha$ (Figure 3d), nuclear translocation of the p65 subunit of NF- $\mathrm{kB}$ (Figure 3d), and the expression of NRF2 target genes (Figure 3f), Se supported the production of COX- and LOX-derived LMs as well as the release of the fatty acid substrates required for LM biosynthesis, reaching significance for the COX-derived LM $\mathrm{TXB}_{2}$ as well as docosahexaenoic acid (DHA) in differentiated macrophages. Interestingly, in undifferentiated Se-deficient cells, almost all lipid mediators were downregulated by LPS by trend but upregulated by Se with significant effects on COX-derived $\mathrm{TXB}_{2}$ and $\mathrm{TXB}_{3}$, and the LOX-derived products 15-hydroxyeicosatetraenoic acid (15-HETE) and 12hydroxypentaenoic acid (12-HEPE), as well as arachidonic acid (AA), eicosapentaenoic acid (EPA), and docosahexaenoic acid (DHA) (Figure 4). Together, our data clearly indicate that Se facilitates LM biosynthesis by modulating the enzymes for LM biosynthesis. 


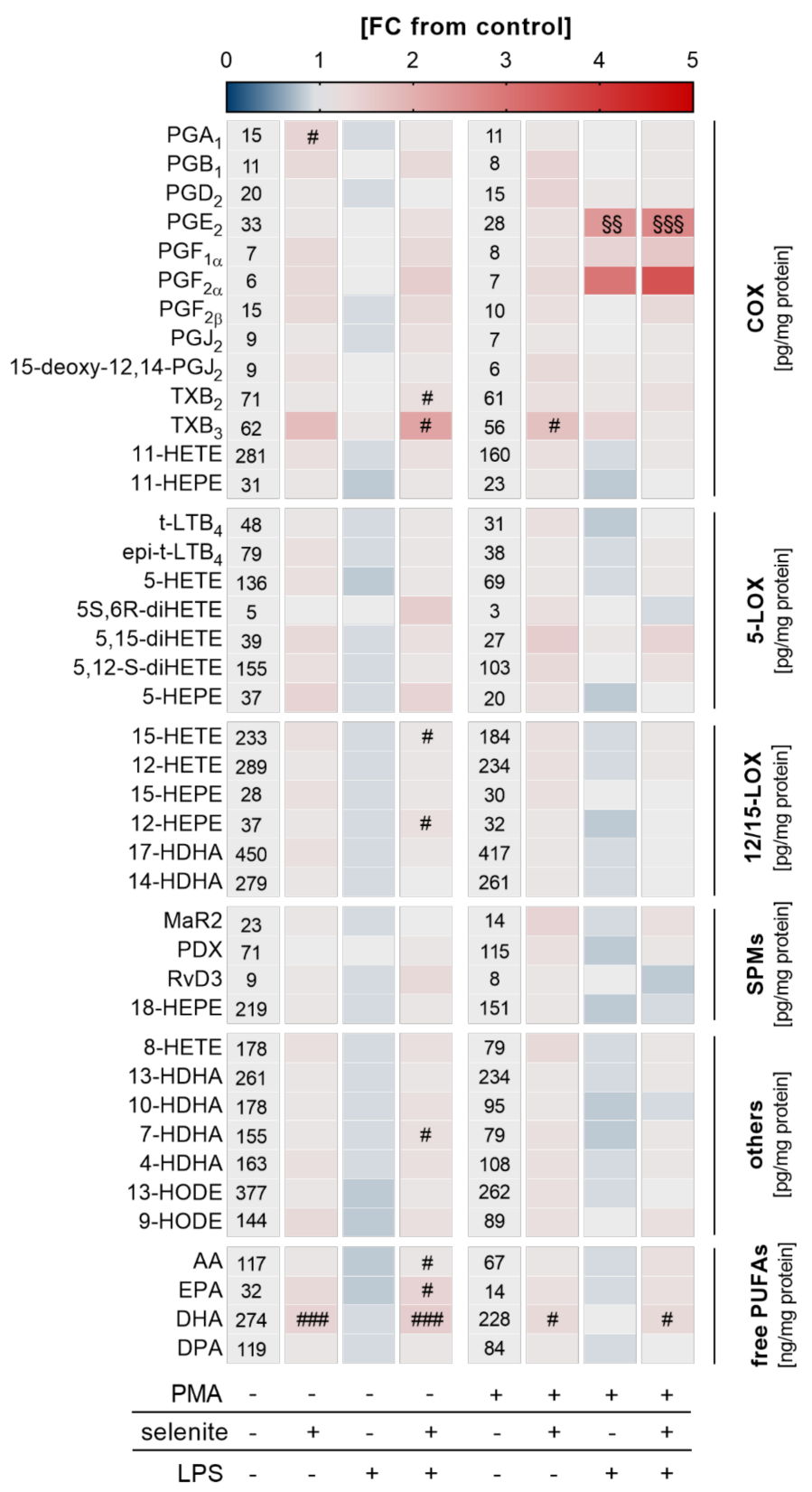

Figure 4. Effect of Se, PMA-induced differentiation, and LPS on lipid mediator (LM) profiles. THP-1 cells were pre-treated with or without $50 \mathrm{nM}$ sodium selenite (selenite) for $72 \mathrm{~h}$ and differentiated into macrophages by treatment with $25 \mathrm{nM}$ PMA in co-treatment with or without $50 \mathrm{nM}$ sodium selenite (selenite) for $48 \mathrm{~h}$ and with or without $1 \mu \mathrm{g} / \mathrm{mL}$ lipopolysaccharide (LPS) for an additional $24 \mathrm{~h}$. LM profiles of the supernatant were analyzed by UPLC-MS/MS. The heatmap organizes LM according to key biosynthetic enzymes $(n=4)$. The values in the columns give the concentrations of LMs in $\mathrm{pg} / \mathrm{mg}$ protein (COX, 5-LOX, 12/15-LOX, SPMs, others) or ng/mg protein (free PUFAs). The color scale indicates the mean difference as fold change (FC) of control cells vs. LPS and/or selenite-treated cells $(\mathrm{FC}=1)$. Two-way ANOVA with Bonferroni's post-test. Significant outliers were determined by Grubbs' test $(\alpha=0.05) .{ }^{\#} p<0.05,{ }^{\# \# \#} p<0.001$ vs. cells without selenite (selenite effect); $\$ \S p<0.01$, $\S \S \S p<0.001$ vs. cells without LPS (LPS effect). AA, arachidonic acid; COX, cyclooxygenase; DHA, docosahexaenoic acid; DPA, docosapentaenoic acid; EPA, eicosapentaenoic acid; HDHA, hydroxydocosahexaenoic acid; HEPE, hydroxypentaenoic acid; HETE, hydroxyeicosatetraenoic acid; HODE, hydroxyoctadecadienoic acid; LOX, lipoxygenase; LT, leukotriene; MaR, maresin; PD, protectin D; PG, prostaglandin; PUFA, polyunsaturated fatty acid; Rv, resolvin; SPM, specialized pro-resolving mediator; TX, thromboxane. 


\section{Discussion}

Since Se was recognized as an essential trace element, the role played by its adequate supply has been intensively studied. Various studies have shown that adequate levels of Se are important for the immune function and are able to prevent excessive inflammation [3]. Hence, Se was found to limit the expression of pro-inflammatory cytokines under inflammatory conditions in vitro at relatively high concentrations of $2 \mu \mathrm{M}$ [29-31]. In vivo effects of Se are more distinct [32,33]. While long-term treatment of mice with $0.6 \mathrm{mg} / \mathrm{kg}$ Se (which was given as sodium selenite and corresponded to approximately four times the adequate intake) had no effects on dextran sulfate sodium (DSS)-induced colitis, short-term treatment with $0.6 \mathrm{mg} / \mathrm{kg}$ Se actually enhanced inflammation scores, as well as TNF $\alpha$ and COX 2 mRNA expression. Notably, $0.6 \mathrm{mg} / \mathrm{kg}$ Se given in the form of selenomethionine had no effect [32]. Otherwise, rats that received $0.2-20 \mu \mathrm{g} / \mathrm{kg}$ organic selenocompounds during pregnancy developed less severe Staphylococcus aureus-induced mastitis with lower NF- $\mathrm{KB}$ activation and TNF $\alpha$ mRNA expression [33]. Within the innate immune system, macrophages inherit key functions in neutralizing pathogens and regulating inflammatory processes and individual selenoproteins have been shown to affect the macrophage maturation process (GPX1 and SELENOP) and limit oxidative burst (SELENOK) [34-38]. However, little is known about how Se deficiency impacts redox-dependent proliferation, differentiation and signaling cascades in monocytes and differentiated macrophages, nor about how selenoprotein expression affects these processes.

Human THP-1 monocytes were used as a model system under Se-deficient as well as Se-adequate conditions and were differentiated into macrophages by PMA. Interestingly, the hierarchy of selenoprotein expression seems to be different in monocytes/macrophages as compared to other cell types, such as epithelial cells. While the Se-sensitive selenoprotein SELENOH was significantly upregulated in a time- and concentration-dependent manner, with fourfold higher expression levels at $500 \mathrm{nM}$ Se, the expression of another Se-sensitive selenoprotein, GPX1, was only slightly affected by Se, being upregulated by 1.5 -fold (Figure S1a,b). Notably, the protein expression of GPX1 and of the protein family member GPX4, which ranks higher in hierarchy, were comparably upregulated by 1.5-1.8-fold by Se, which indicates that GPX1 is more indispensable in THP-1 monocytes compared to other cell types (Figures 2a and S2a). This might be due to the absence of another GPX isoenzyme in monocytes, GPX2 [35], which has been previously shown to have overlapping functions with GPX1 in limiting the redox-dependent activation of the NF- $k B$ pathway and LM biosynthesis in human epithelial-derived cancer cells [29]. It is therefore tempting to speculate that the absence of the epithelial GPX2 makes GPX1 more indispensable in THP-1 monocytes, thereby advancing GPX1 in hierarchy.

Interestingly, the PMA-induced differentiation process was also not significantly affected by Se status, as suggested from cell adherence, granularity, autofluorescence, and surface marker expression (Figure $1 \mathrm{~b}-\mathrm{e}$ ). However, the differentiation process had a strong impact on the protein expression levels of various selenoproteins (Figures 2 and S2). Expression of the two GPX isoenzymes GPX1 and GPX4 was differently regulated by PMA. Whereas GPX1 protein expression was not affected by PMA treatment (Figure S2a), GPX4 protein expression was downregulated under both Se-deficient as well as Se-adequate conditions by PMA-induced differentiation (Figure 2a). Notably, mRNA expression levels of selenoproteins did not correlate with protein expression levels and were upregulated by PMA treatment for all selenoproteins except for SELENOO (Figure 2e). We could exclude (i) Se levels, (ii) impaired selenocysteine biosynthesis, and (iii) selenoprotein translation as limiting variables for the PMA-induced reduction of several selenoproteins since the cellular Se content as well as mRNA expression of proteins responsible for selenocysteine biosynthesis and selenoprotein translation were not affected or even upregulated by PMA (Figure 2e,f). We therefore speculate that the upregulation of selenoprotein mRNAs is due to the special M0 state of macrophages, which has to be considered as a transitional rather than a terminal stage. Depending on the milieu in the tissue, M0 macrophages polarize into various subpopulations with either pro- or anti-inflammatory properties. Hence, 
mRNA levels of the selenoproteins might be kept at relatively high levels to rapidly adapt the protein expression of selenoproteins to the requirement of the respective macrophage subtype after maturation.

GPX4 has been shown to inhibit NF-kB activation [39], and the downregulation of GPX4 in differentiated THP-1 macrophages might be essential to enable inflammatory responses in these cells. Accordingly, NF- $\mathrm{KB}$ target genes TNF $\alpha$ and COX2 were upregulated by PMA (Figure 3d). Moreover, TNF $\alpha$ and COX2 mRNA expression as well as the release of COX-derived $\mathrm{PGE}_{2}$ and $\mathrm{PGF}_{2 \alpha}$ were increased by LPS stimulation in macrophages, with more distinct effects under Se treatment (Figures 3 and 4). However, the Se effect on TNF $\alpha$ and COX2 expression was not present for protein levels (Figures 3e and S3a). Possibly, Se effects on protein expression are only visible within another time frame which was not captured by our study $(24 \mathrm{~h})$. Essentially, previous studies indicate that the Se effects on biosynthesis of pro-inflammatory cytokines differ at different time points $[30,40]$. Importantly, a rapid and adequate secretion of inflammatory cytokines upon bacterial or viral infection is essential in pathogen removal and to prevent sustained inflammation. Optimal Se supply might be important to maintain homeostasis between the formation of inflammation-dependent production of reactive oxygen species and the antioxidant NRF2 system, thereby enabling cells' fast upregulation of inflammatory response upon stimulation, and to prevent chronic inflammation [41]. Inversely, physiological changes in Se levels as studied herein only moderately impacted on NF-kB signaling and LM biosynthesis, which indicates that THP-1 cells are able to compensate for the reduced expression of selenoproteins. Otherwise, expression of selenoproteins that are important for the regulation of inflammatory signaling might be less dependent on Se in macrophages, as demonstrated for GPX1 and TXNRD1 (Figure S2a,c).

Interestingly, the release of other COX-derived products was enhanced neither by PMA nor by LPS (Figure 4), which indicates that LM biosynthesis is efficiently channeled into $\mathrm{PGE}_{2}$ and $\mathrm{PGF}_{2} \alpha$ production. Notably, previous studies reported that Se treatment decreased the expression of pro-inflammatory cytokines such as TNF $\alpha$ and the release of LMs including $\mathrm{PGE}_{2}$ in macrophages [29-31,33,40,42,43]. Differences in the study outcomes might have been related to different experimental settings. While our study used human THP-1 macrophages treated with physiological concentrations of Se (50 nM), previous studies employed murine RAW264.7 and bone marrow-derived macrophages (BMDM) treated with $2 \mu \mathrm{M}$ Se (given as sodium selenite). Hence, even striking differences in the Se-dependent regulation of COX2 expression are observed in RAW264.7 and BMDM cells under similar experimental conditions $(2 \mu \mathrm{M} \mathrm{Se})$, with strong effects of Se $(2 \mu \mathrm{M})$ on COX2 expression in RAW264.7 and noticeably less pronounced effects in the BMDM cells [30]. Moreover, another study showed that TNF $\alpha$ mRNA expression in Staphylococcus aureusstimulated RAW264.7 macrophages was significantly reduced by $2 \mu \mathrm{M}$ Se (given as sodium selenite) and unaffected by $1-1.5 \mu \mathrm{M}$ [40], which underlines the concentration dependency of the Se effects. Notably, while an adequate supply with Se is supposed to have antioxidant properties via the upregulation of selenoproteins, Se given at concentrations that exceed the dosage required to maximize selenoprotein expression most likely does not exert its effects via selenoproteins and can even have pro-oxidant effects, which underscores the necessity of a well-balanced Se status [44-46]. Another critical aspect of an appropriate immune reaction might be that related to an accurate time-dependent regulation of the inflammatory response. While an upregulation of COX2 expression after infection is required to remove pathogens, an excessively prolonged activation might result in chronic inflammation. Overall, it appears that moderate changes in the Se supply do not overtly change the expression of NF-kB-responsive proteins and thus the immune response of THP-1 monocytes and M0 macrophages.

Analog with NF-kB, mRNA expression levels of NRF2 target genes were increased by LPS stimulation and were dependent on adequate Se levels in macrophages (Figure 3f). The increase of NRF2 target gene transcription by LPS is in line with a previous report which also observed an upregulation of NRF2 upon activation of the toll-like receptor $1 / 2$ 
with Pam3CSK4 in THP-1 cells [47]. Given that the NF- $\mathrm{kB}$ and NRF2 signaling pathways are interconnected via a complex signaling network, the coordinated increase in NF- $\mathrm{kB}$ and NRF2 target gene expression upon LPS stimulation by Se hints towards an important function in maintaining a balance of NF-kB-dependent reactive oxygen species/reactive nitrogen species formation and NRF2-dependent hydrogen peroxide detoxification in THP-1-derived macrophages. Otherwise, Se downregulated most of the NRF2 target genes under unstimulated conditions in macrophages, reaching significance for GCLC (Figure 3f). This is in line with a previous in vivo study which found that mRNA expression of the NRF2 target genes GCLC, NQO1, SOD1, and SRXN1 was significantly downregulated in mice that received a Se-adequate diet $(0.15 \mathrm{mg} / \mathrm{kg})$ compared to mice with a Se-poor diet $(0.086 \mathrm{mg} / \mathrm{kg})$ [48]. Notably, while most of the NRF2 target genes were upregulated by PMA-induced differentiation, the two target genes CAT and SLC7A11 were downregulated (Figure 3f). NRF2-dependent target gene expression is regulated by complex mechanisms, which include: (i) different cysteine sensors within the NRF2 regulatory protein KEAP1 (Cys151, Cys257, Cys273, Cys288, and Cys297) that can be targeted by distinct endogenous and exogenous ligands, (ii) phosphorylation of NRF2, and (iii) transactivation via dimerization with different transcription factors (e.g., activating transcription factor 4 (ATF4), ATF3 or CREB binding protein (CBP)) and nuclear receptors (e.g., peroxisome proliferator-activated receptor gamma (PPAR $\gamma$ ), estrogen receptor $\alpha$, and retinoic $\mathrm{X}$ receptor $\alpha(R X R \alpha))$ [15]. How exactly PMA stimulates NRF2 activation is not known. However, a similar controversial regulation of NRF2 target gene subsets has also been observed with other small molecule inducers of NRF2, such as Bay 11-7085 [49] and sulforaphane [50], which stimulate ferroptosis and induce a strong upregulation of HMOX1 with concomitant downregulation of other NRF2 target genes like GPX4 and SLC7A11, respectively. Depending on the point of attack, small molecule inducers of NRF2 might therefore reveal a specific profile of NRF2 target gene regulation.

In conclusion, we anticipate that adequate Se levels as well as differentiation impact on selenoprotein expression, whereas the Se status only moderately affected NF- $\mathrm{\kappa B}$ signaling and biosynthesis of inflammatory LMs. Of particular interest are the discrepancies with previous findings that indicated an inhibitory effect of Se on NF-kB-dependent inflammatory signaling; our results indicate that Se facilitates LPS-induced NF- $\mathrm{KB}$ activation. We speculate that differences arise from (i) different Se concentrations and (ii) timing and maybe even the species (e.g., human vs. mouse). Notably, PMA, which was used for differentiation, had significant effects on NF- $\mathrm{kB}$ as well as NRF2 that might have impacted the overall effects of Se in our THP-1 model system. However, the well-known effects of physiological Se levels for a fine-tuned adaptive immune response upon bacterial and viral infections [51,52], as well as during inflammation resolution [53-55], might be mediated by other mechanisms as well. Further concentration- and time-dependent studies on inflammatory responses upon inflammatory stimulation are required, as are investigations in primary cells which more closely reflect in vivo conditions and research on the function of specific selenoproteins in order to address these issues.

\section{Materials and Methods}

\subsection{Materials}

Materials are listed in Table S1.

\subsection{Cell Culture}

Human THP-1 acute monocytic leukemia cells (monocytes, ATCC ${ }^{\circledR}$ TIB-202 ${ }^{\mathrm{TM}}$ ) were grown in RPMI completed with 10\% (v/v) FCS, 1\% (v/v) penicillin-streptomycin and $1 \%$ GlutaMAX at $37^{\circ} \mathrm{C}$ in $5 \% \mathrm{CO}_{2}$ and sub-cultured every three to five days. Cell treatment: THP-1 monocytes were incubated with different concentrations of Se $(0-500 \mathrm{nM})$ for $72 \mathrm{~h}$ or for varying incubation times $(0-96 \mathrm{~h})$ with $50 \mathrm{nM} \mathrm{Se}$. THP-1 monocytes were differentiated with different PMA $(0-400 \mathrm{nM})$ concentrations as indicated or with $25 \mathrm{nM}$ PMA for $48 \mathrm{~h}$ or as indicated. THP-1 monocytes were preincubated for $72 \mathrm{~h}$ with or without $50 \mathrm{nM}$ 
Se, seeded at densities of $0.5 \times 10^{5}$ cells $/ \mathrm{mL}$ THP- 1 monocytes (DMSO control) and $2.5 \times 10^{5} / \mathrm{mL}$ for PMA-induced differentiation with or without Se $(50 \mathrm{nM})$ treatment, and harvested after $48 \mathrm{~h}$. LPS $(1 \mu \mathrm{g} / \mathrm{mL})$ stimulation was performed with undifferentiated and differentiated THP-1 cells with or without Se treatment for $1 \mathrm{~h}$ (nuclear extracts for Western blot analysis), $6 \mathrm{~h}$ (quantitative real-time PCR analysis) or $24 \mathrm{~h}$ (Western blot and LM analysis). The protein content of the cell lysates was measured using Bradford analysis (Bio-Rad Laboratories).

\subsection{Determination of Adherence, Morphology and Cell Number}

Adherence of PMA-treated THP-1 cells was determined at the indicated time points. Cells were harvested by trypsinization and resuspended in RPMI. The cell number was determined using $0.4 \%$ trypan blue staining with a Vi-Cell XR Cell Viability Analyzer (Beckman Coulter, Brea, CA, USA). To determine the relative adherence, adherent cells were collected and percentage adherence was calculated as the number of adherent cells divided by the starting cell number and multiplied by 100 .

Images of cells were collected with an Eclipse Ti-S microscope (Nikon GmbH, Tokyo, Japan) equipped with a Nikon Digital Sight DS-Fi1c color camera (Nikon $\mathrm{GmbH}$ ) and a $20 \times$ objective $(\mathrm{NA}=0.45, \mathrm{~S}$ Plan Fluor, Nikon $\mathrm{GmbH})$ or a $10 \times$ objective $(\mathrm{NA}=0.3$, Plan Fluor, Nikon GmbH).

\subsection{Flow Cytometry}

For flow cytometry experiments, cells were treated as described above and harvested. Granularity was measured using forward and side scatter light and autofluorescence analyzed in unstained cells in the FL-1 channel (blue laser, excitation 488, emission 525/40). For detection of the cell surface marker CD68, cells were resuspended in ice cold primary antibody solution (containing phosphate-buffered saline (PBS, $140 \mathrm{mM} \mathrm{NaCl}, 10 \mathrm{mM}$ $\mathrm{Na}_{2} \mathrm{HPO}_{4}$, and $2.99 \mathrm{mM} \mathrm{KH}_{2} \mathrm{PO}_{4}, \mathrm{pH} 7.4$ ) with $10 \%$ FCS and $1 \% \mathrm{NaN}_{3}$ ), fixed with PBS and $0.01 \%$ formaldehyde (diluted in PBS) for $15 \mathrm{~min}$, and washed with primary antibody solution. Cells were resuspended in primary antibody solution with $0.5 \%(v / v)$ Tween ${ }^{\circledR}$ 20 and incubated with primary antibody mouse anti-CD68 (1:200) for $30 \mathrm{~min}$. Samples were centrifuged for $3 \mathrm{~min}$ at $500 \times g$ and washed twice in primary antibody solution and once in secondary antibody solution (containing PBS with 3\% BSA and 1\% $\mathrm{NaN}_{3}$ ) with the same centrifugation steps in between. Samples were incubated with the secondary antibody (anti-mouse IgG Alexa Fluor ${ }^{\circledR} 594$ Conjugate (1:1000)) for 30 min protected from light. Analysis was performed on a CytoFLEX flow cytometer (Beckman Coulter, excitation: $488 \mathrm{~nm}$; emission: 525/40 nm) and data were analyzed using CytExpert software version 2.2 and version 2.3 (Beckman Coulter).

\subsection{Nuclear Isolation}

The nuclear lysates of $3.0 \times 10^{5} / \mathrm{mL}$ PMA-differentiated macrophages were harvested after $1 \mathrm{~h}$ of LPS stimulation. Lysis buffer I (10 mM HEPES, $1.5 \mathrm{mM} \mathrm{MgCl} 2,10 \mathrm{mM}$ $\mathrm{KCl}, 0.5 \mathrm{mM}$ DTT, $0.5 \mathrm{mM}$ PMSF, and $0.1 \% \mathrm{NP}-40$ Alternative, $\mathrm{pH} 7.9$ ) was used. After incubation for $7 \mathrm{~min}$ at $4{ }^{\circ} \mathrm{C}$ under shaking, cells were centrifuged for $1 \mathrm{~min}$ at $4{ }^{\circ} \mathrm{C}$ and $6800 \times \mathrm{g}$. Thereafter, $\mathrm{NaCl}(5 \mathrm{M})$ was added to the lysis buffer II ( $40 \mathrm{mM}$ HEPES, $400 \mathrm{mM}$ $\mathrm{KCl}, 10 \%$ glycerol, $1 \mathrm{mM} \mathrm{DTT}$, and $0.1 \mathrm{mM}$ PMSF, $\mathrm{pH} 7.9)$ and the cell pellet was lysed by ultrasonic treatment ( $80 \%$ amplitude, $0.5 \mathrm{~s}$ cycle), and centrifuged for $30 \mathrm{~min}$ at $4{ }^{\circ} \mathrm{C}$ and $20,000 \times g$ to obtain nuclear lysates. The protein content was measured and the nuclear lysate was used for Western blot analysis.

\subsection{Western Blot}

Harvested THP-1 monocytes and macrophages were lysed with RIPA buffer $(50 \mathrm{mM}$ Tris, $150 \mathrm{mM} \mathrm{NaCl}, 2 \mathrm{mM}$ EDTA, $0.5 \%$ sodium deoxycholate, $0.1 \%$ SDS, and $1 \%$ NP-40 Alternative, $\mathrm{pH} 7.7$ with $0.1 \%(\mathrm{v} / \mathrm{v})$ protease inhibitor) for $15 \mathrm{~min}$ at $4{ }^{\circ} \mathrm{C}$ and $1200 \mathrm{rpm}$ using the ThermoMixer ${ }^{\circledR}$ (Eppendorf AG, Hamburg, Germany). The samples were cen- 
trifuged for $15 \mathrm{~min}$ at $4{ }^{\circ} \mathrm{C}$ and $14,000 \times g$, and protein concentration was determined in the supernatant. Samples were mixed with loading buffer $(1 \times ; 41.7 \mathrm{mM}$ Tris $\mathrm{pH} 6.8,10 \%$ glycerin, $2 \%$ SDS, $0.125 \%$ bromophenol blue, and $2.5 \% \beta$-mercaptoethanol) and heated for $5 \mathrm{~min}$ at $95{ }^{\circ} \mathrm{C}$. Proteins were separated on SDS polyacrylamide gels (10-15\%) and immunoblotted on Amersham ${ }^{\mathrm{TM}}$ Protran ${ }^{\circledR}$ nitrocellulose membrane. Membranes were incubated for $2 \mathrm{~min}$ in Ponceau S solution $(0.2 \%(w / v)$ with $3 \%(w / v)$ trichloroacetic acid) and bands were recorded by a ChemiDoc ${ }^{\mathrm{TM}} \mathrm{MP}$ Imaging System (Bio-Rad Laboratories). Subsequently, membranes were blocked in $5 \%(w / v)$ non-fat dry milk in Tris-buffered saline ( $5 \mathrm{mM}$ Tris, $15 \mathrm{mM} \mathrm{NaCl}$ ) with $0.1 \%(v / v)$ Tween ${ }^{\circledR} 20$ (T-TBS) for $1 \mathrm{~h}$ at room temperature and incubated with primary antibodies overnight at $4{ }^{\circ} \mathrm{C}$ in T-TBS: Mouse anti- $\gamma$-GCSc (H-5) (1:10,000), mouse anti-mPGES1 (1:300); rabbit anti-beta actin (1:10,000); rabbit antioxidative stress defense (catalase, SOD1) (1:500); rabbit anti-COX2 (D5H5) XP ${ }^{\circledR}(1: 1000)$; rabbit anti-GPX1 (1:5000); rabbit anti-GPX4 (1:5000); rabbit anti-NF-kB p65 (D14E12) XP ${ }^{\circledR}$ (1:4000); rabbit anti-p21WAF1/Cip1 (12D1) (1:1000); rabbit anti-SEP15 (1:3000); rabbit anti-SELH (1:1000); rabbit anti-SELO (1:2500); rabbit anti-VIMP (D1D1M)) (1:1000); rabbit anti-TXNRD1 (1:10,000); and rabbit anti-TXNRD2 (1:1000). HRP-coupled goat anti-rabbit $\operatorname{IgG}(1: 50,000)$ or HRP-coupled horse anti-mouse IgG $(1: 3000)$ were used as secondary antibody. Protein bands were detected using SuperSignal ${ }^{\mathrm{TM}}$ West Dura and band intensities were densitometrically quantified using a ChemiDoc ${ }^{\mathrm{TM}}$ MP Imaging System (Bio-Rad Laboratories) and data analyzed using Image Lab software version 5.0 (Bio-Rad Laboratories). Protein expression was normalized to $ß$-actin or Ponceau $S$ staining as indicated.

\subsection{Quantitative Real-Time PCR}

Total mRNA of THP-1 cells was isolated using the Dynabeads ${ }^{\mathrm{TM}}$ mRNA DIRECT ${ }^{\mathrm{TM}}$ Purification Kit according to the manufacturer's protocol. The SensiFAST ${ }^{\mathrm{TM}}$ CDNA Synthesis Kit was used for cDNA transcription. For real-time PCR, cDNA were combined with Master mix (PerfeCTa SYBR Green Supermix, forward and reverse primer (each $250 \mathrm{nM}$ final concentration)) in a 96-well plate as previously described [56]. Primer sequences are given in Table 1. PCR was performed on a real-time PCR system (MX3005P, Agilent, Santa Clara, CA, USA) with heat cycle to $95^{\circ} \mathrm{C}$ for $3 \mathrm{~min}, 40$ cycles of denaturation at $95{ }^{\circ} \mathrm{C}$ for $15 \mathrm{sec}$, annealing at $60^{\circ} \mathrm{C}$ for $20 \mathrm{~s}$, and elongation at $72{ }^{\circ} \mathrm{C}$ for $30 \mathrm{sec}$. Standard curves from diluted PCR products were used for quantification and all samples and standards were measured in triplicate. For normalization, sample values were normalized to a composite factor based on the reference genes RPL13a and RPS9. MIQE guidelines served as reference for the quantification procedure.

Table 1. Human-specific primers for quantitative real-time PCR.

\begin{tabular}{|c|c|c|}
\hline Gene & RefSeq-ID & Sequence $\left(5^{\prime} \rightarrow 3^{\prime}\right)$ \\
\hline ALOX15 (arachidonate 15-lipoxygenase) & NM_001140.3 & $\begin{array}{l}\text { TGGAGCCTTCCTAACCTACAG } \\
\text { TCCACATACCGATAGATGATTTCC }\end{array}$ \\
\hline ALOX5 (arachidonate 5-lipoxygenase) & NM_000698.3 & $\begin{array}{l}\text { GCTGCAACCCTGTGTTGATCC } \\
\text { AAATGTTCCCTTGCTGGACCTC }\end{array}$ \\
\hline CAT (catalase) & NM_001752.4 & $\begin{array}{l}\text { CCTATCCTGACACTCACCGCCA } \\
\text { GAGCACCACCCTGATTGTCCTG }\end{array}$ \\
\hline $\begin{array}{c}\text { COX2 (cyclooxygenase 2; } \\
\text { prostaglandin-endoperoxide synthase } 2 \text { (PTGS2)) }\end{array}$ & NM_000963.2 & $\begin{array}{l}\text { CCCAGCACTTCACGCATCAG } \\
\text { CTGTCTAGCCAGAGTTTCACCGT }\end{array}$ \\
\hline $\begin{array}{l}\text { EEFSEC (eukaryotic elongation factor, } \\
\text { selenocysteine-tRNA-specific) }\end{array}$ & NM_021937.3 & $\begin{array}{l}\text { CCCTAGAGAACACCAAGTTCCGAG } \\
\text { TCAATGAGCTCTGGAATGCCCT }\end{array}$ \\
\hline EIF4A3 (eukaryotic translation initiation factor 4A3) & NM_014740.3 & $\begin{array}{l}\text { AAAGAAAGGTGGACTGGCTGACGG } \\
\text { ACTCCTTCATGATGGACTCCCGCT }\end{array}$ \\
\hline GCLC (glutamate-cysteine ligase catalytic subunit) & NM_001498.3 & $\begin{array}{l}\text { TGCTGTCTCCAGGTGACATTCCA } \\
\text { GGAGATGCAGCACTCAAAGCCA }\end{array}$ \\
\hline GCLM (glutamate-cysteine ligase modifier subunit) & NM_002061.3 & $\begin{array}{l}\text { GTTGACATGGCCTGTTCAGTCCT } \\
\text { CCCAGTAAGGCTGTAAATGCTCCA }\end{array}$ \\
\hline GPX1 (glutathione peroxidase 1) & NM_000581.2 & $\begin{array}{l}\text { TACTTATCGAGAATGTGGCGTCCC } \\
\text { TTGGCGTTCTCCTGATGCCC }\end{array}$ \\
\hline
\end{tabular}


Table 1. Cont.

\begin{tabular}{|c|c|c|}
\hline Gene & RefSeq-ID & Sequence $\left(5^{\prime} \rightarrow 3^{\prime}\right)$ \\
\hline GPX3 (glutathione peroxidase 3) & NM_002084.5 & $\begin{array}{l}\text { GTCGAAGATGGACTGCCATGGT } \\
\text { AGCTGGCCACGTTGACAAAGAG }\end{array}$ \\
\hline GPX4 (glutathione peroxidase 4) & NM_002085.3 & $\begin{array}{l}\text { AGGCAAGACCGAAGTAAACTACAC } \\
\text { TCTCTTCGTTACTCCCTGGCT }\end{array}$ \\
\hline GSS (glutathione synthesis) & NM_000178.2 & $\begin{array}{l}\text { CCAAGTGCCCAGACATTGCCA } \\
\text { CСTTCTTCACCCACATCCAGTGAG }\end{array}$ \\
\hline HMOX1 (heme oxygenase 1) & NM_002133.2 & $\begin{array}{l}\text { CAACAAAGTGCAAGATTCTGCCC } \\
\text { CTACAGCAACTGTCGCCACC }\end{array}$ \\
\hline NOX2 (NADPH oxidase 2) & NM_000397.3 & $\begin{array}{l}\text { TCACCAAGGTGGTCACTCACCC } \\
\text { TGCCACTCCAGCTTGGACAC }\end{array}$ \\
\hline NQO1 (NAD(P)H quinone oxidoreductase 1) & NM_001025434.1 & $\begin{array}{l}\text { CATCACAGGTAAACTGAAGGACCC } \\
\text { CTCTGGAATATCACAAGGTCTGCG }\end{array}$ \\
\hline PGES (prostaglandin E synthase) & NM_004878.3 & $\begin{array}{l}\text { ACGCTGCTGGTCATCAAGATG } \\
\text { TGGCAAAGGCCTTCTTCCGC }\end{array}$ \\
\hline PSTK (phosphoseryl-tRNA kinase) & NM_153336 & $\begin{array}{l}\text { TTTGAGGCCCAGTCTTGCTACC } \\
\text { GCCCAACGAATATTTCCGAGCC }\end{array}$ \\
\hline RPL13a (ribosomal protein L13a) & NM_012423.4 & $\begin{array}{l}\text { GAGGTTGGCTGGAAGTACCAGG } \\
\text { TGTTTCCGTAGCCTCATGAGCTG }\end{array}$ \\
\hline RPS9 (ribosomal protein S9) & NM_001013.4 & $\begin{array}{l}\text { CCATATCAGGGTCCGCAAGCA } \\
\text { GGCCCTTCTTGGCATTCTTCCT }\end{array}$ \\
\hline SECISBP2 (SECIS-binding protein 2) & NM_024077.4 & $\begin{array}{l}\text { TGAAGAGCCACCAGGCACAG } \\
\text { GCATCTGGCTGCAGTAATCCCT }\end{array}$ \\
\hline SELENBP1 (selenium-binding protein 1) & NM_009150.3 & $\begin{array}{l}\text { TTCCCTTGGAGATCCGCTTCCT } \\
\text { ACTGACCATGTACCTCCСTCGT }\end{array}$ \\
\hline SELENOF (selenoprotein F) & NM_203341.1 & $\begin{array}{l}\text { TGATCTTCTCGGACAGTTCAACCT } \\
\text { CACGGACATACTTGGACTTGAGGG }\end{array}$ \\
\hline $\begin{array}{l}\text { SELENOH (C11orf31, chromosome } 11 \text { open reading } \\
\text { frame 31; selenoprotein } \mathrm{H} \text { ) }\end{array}$ & NM_170746.2 & $\begin{array}{l}\text { GCTTCCAGTAAAGGTGAACCCGA } \\
\text { TCAGGGAATTTGAGTTTGCGTGG }\end{array}$ \\
\hline SELENOI (selenoprotein I) & NM_033505.4 & $\begin{array}{l}\text { ATGCCTCAGCACCAGGTCAC } \\
\text { GTTCTGCGAGCTTGCTTTCCGT }\end{array}$ \\
\hline SELENOK (selenoprotein K) & NM_021237.3 & $\begin{array}{l}\text { GATGATGGAAGAGGGCCACCAG } \\
\text { CGCATGTCCGGTTGTCTGCT }\end{array}$ \\
\hline SELENOM (selenoprotein M) & NM_080430.2 & $\begin{array}{l}\text { TGAAGGCTTTCGTCACGCAG } \\
\text { AGTGGGATGCGCTCTAGTTCCT }\end{array}$ \\
\hline SELENON (selenoprotein N) & NM_206926.2 & $\begin{array}{l}\text { TGTGATGTTCCGGATCCATGCC } \\
\text { TGTGGTTGGGCACGAAGAGC }\end{array}$ \\
\hline SELENOO (selenoprotein O) & NM_031454.1 & $\begin{array}{l}\text { TGACGCCGAGTTCCAAAGGCA } \\
\text { TTGTGAAGTCGGCACCGGTCAG }\end{array}$ \\
\hline SELENOP (selenoprotein P) & NM_005410 & $\begin{array}{l}\text { GAAACTCCATCGCCTCATTACCAT } \\
\text { CTGCCTATGCTGACCCTTGTG }\end{array}$ \\
\hline SELENOS (selenoprotein S, VIMP) & NM_203472.1 & $\begin{array}{l}\text { GCTGCATCCTTCTCTACGTGGTC } \\
\text { CAACAACATCAGGTTCCACAGCA }\end{array}$ \\
\hline SELENOT (selenoprotein T) & NM_016275.3 & $\begin{array}{l}\text { CGATCATAGCACCACCTATCAGCA } \\
\text { GAGCCTGCCAAGAAAGCATCTG }\end{array}$ \\
\hline SEPHS2 (selenophosphate synthetase 2) & NM_012248.4 & $\begin{array}{l}\text { GACGGTTTGGGCTTCTTCAAGG } \\
\text { TCCACAATGCCAACGATCCAC }\end{array}$ \\
\hline $\begin{array}{l}\text { SEPSECS (sep (o-phosphoserine) tRNA:sec } \\
\text { (selenocysteine) tRNA synthase) }\end{array}$ & NM_016955.3 & $\begin{array}{l}\text { CTAGTGCTCCCGCTTATTCGCC } \\
\text { CTGGACACTTGCCCTTCTCCAG }\end{array}$ \\
\hline SLC7A11 (solute carrier family 7 member 11 ) & NM_014331.3 & $\begin{array}{l}\text { TGCTCTTCTCTGGAGACCTCGAC } \\
\text { ACAGTGGCACCTTGAAAGGACG }\end{array}$ \\
\hline SOD1 (superoxide dismutase 1) & NM_000454.4 & $\begin{array}{l}\text { TACAGCAGGCTGTACCAGTGCA } \\
\text { TCGGCCACACCATCTTTGTCAG }\end{array}$ \\
\hline SRXN1 (sulfiredoxin 1) & NM_080725.1 & $\begin{array}{l}\text { CTCAGTGCTCGTTACTTCATGGTC } \\
\text { GTTTGGCCCTTCСTCTTCCTCC }\end{array}$ \\
\hline TNFA (tumor necrosis factor $\alpha$ ) & NM_000594.2 & $\begin{array}{l}\text { AGCCCATGTTGTAGCAAACCCT } \\
\text { GGAGTAGATGAGGTACAGGCCC }\end{array}$ \\
\hline
\end{tabular}


Table 1. Cont.

\begin{tabular}{cll}
\hline Gene & RefSeq-ID & \multicolumn{1}{c}{${\text { Sequence }\left(\mathbf{5}^{\prime} \rightarrow \mathbf{3}^{\prime}\right)}^{\prime}$} \\
\hline TXAS1 (thromboxane A synthase 1) & NM_001061.4 & CCTGAAAGGTTCACGGCTGAG \\
TXNRD1 (thioredoxin reductase 1) & NM_182742.1 & GTGTTGTGGGCCTCATCACGGCCCT \\
TXNRD2 (thioredoxin reductase 2) & TGTTGTGAATACCTCTGCACAGAC \\
& NM_006440.5 & GTTCCCACGACCGTCTTCAC \\
\hline
\end{tabular}

\subsection{ELISA}

Incubation medium from seeded cells was collected and the content of TNF $\alpha$ was determined according to the manufacturer's protocol using a microplate reader (Synergy H1, BioTek, Bad Friedrichshall, Germany). A Human TNF $\alpha$ Pre-Coated ELISA Kit was used. The incubation medium of THP-1 monocytes (DMSO control) was diluted 1:2 and for PMA-induced differentiated macrophages 1:50. A standard curve was used to generate a four-parameter logistic curve-fit and to calculate the content of TNF $\alpha$ which was normalized to the protein content of the cells.

\subsection{Trace Element Analysis by Total Reflection X-ray Fluorescence (TXRF) Spectroscopy}

TXRF was used to determine the intracellular levels of Se. Harvested THP-1 monocytes and macrophages were collected and lysed as described in Section 4.6. Cellular debris was removed by centrifugation for $10 \mathrm{~min}$ at $4{ }^{\circ} \mathrm{C}$ and $15,000 \times g$. Trace elements analysis was performed using the supernatant (S2 Picofox ${ }^{\mathrm{TM}}$, Bruker Nano GmbH, Berlin, Germany), and $1 \mathrm{mg} / \mathrm{L}$ yttrium was used as internal standard. Ten microliters of each sample was placed on a siliconized quartz glass carrier and dried for $30 \mathrm{~min}$ at $40{ }^{\circ} \mathrm{C}$. Samples were measured randomized in triplicate for $1000 \mathrm{~s}$ respectively. The Se content was normalized to the protein content of the samples.

\subsection{GSH Assay}

For the measurement of the total GSH content, cells were harvested, resuspended in $150 \mu \mathrm{L}$ ice-cold $10 \mathrm{mM} \mathrm{HCl}$, and lysed by ultrasonic treatment ( $80 \%$ amplitude, $0.5 \mathrm{~s})$. Cellular debris was removed by centrifugation for $30 \mathrm{~s}$ at $8000 \times g$ at room temperature. Then, $30 \mu \mathrm{L}(w / v) 5 \%$ SSA was added to the supernatant, incubated for $10 \mathrm{~min}$, and centrifuged for $15 \mathrm{~min}$ at $4{ }^{\circ} \mathrm{C}$ and $8000 \times g$ at $4{ }^{\circ} \mathrm{C}$, and supernatant was used for GSH measurement. After addition of $10 \mathrm{mM}$ DTNB, the formed 2-nitro-5-thiobenzoic acid (TNB) was measured on a microplate reader (Synergy H1) at $412 \mathrm{~nm}$ for $5 \mathrm{~min}$ with path-length correction, as previously described [57]. BSO $(0.25 \mathrm{mM})$ was used as control for GSH depletion and added $24 \mathrm{~h}$ before the cell harvest. A standard curve was used to calculate the total GSH content, which was normalized to the protein content of the samples.

\subsection{Enzyme Activities}

Cells were homogenized with a TissueLyser II (Qiagen, Hilden, Germany) in Tris buffer $(100 \mathrm{mM}$ Tris, $300 \mathrm{mM} \mathrm{KCl}$, pH 7.6 with $0.1 \%(v / v)$ Triton $\mathrm{X}-100$, and $0.1 \%(v / v)$ protease inhibitor) twice for $60 \mathrm{~s}$ at $30 \mathrm{~Hz}$ and centrifuged for $10 \mathrm{~min}$ at $4{ }^{\circ} \mathrm{C}$ and $14,000 \times g$. The enzymatic activity was normalized to the protein content of the samples.

NQO1 activity was measured via menadione-dependent reduction of MTT as previously described [58]. Briefly, cell lysates were mixed with reaction buffer. Incubation mixtures contained $25 \mathrm{mM}$ Tris, $\mathrm{pH} 7.4,0.665 \mathrm{mg} / 1 \mathrm{BSA}, 0.01 \%$ Tween $^{\circledR} 20,5 \mu \mathrm{M}$ FAD, $1 \mathrm{mM}$ D-glucose-6-phosphate, 35 MM NADP, 0.72 mM MTT, $0.3 \mathrm{U} / \mathrm{mL}$ glucose-6-phosphate dehydrogenase, and $50 \mu \mathrm{M}$ menadione. Absorbance was measured at $590 \mathrm{~nm}$ for $5.5 \mathrm{~min}$ using a microplate reader (Synergy H1) with path-length correction. Differences between the MTT reduction rates with and without dicumarol (final concentration $60 \mu \mathrm{M}$ in phos- 
phate buffer (1 $\mathrm{mM} \mathrm{KH}_{2} \mathrm{PO}_{4}, \mathrm{pH} 7.4$ and $0.1 \%$ DMSO) were used for calculation of NQO1 activity $\left(\varepsilon_{590 \mathrm{~nm}}=11.961 \mathrm{mM}^{-1} \times \mathrm{cm}^{-1}\right)$. Data are given as $\mathrm{mUnit}(\mathrm{mU}) / \mathrm{mg}$ protein.

GPX activity was measured by a GR-coupled test with NADPH consumption using $\mathrm{H}_{2} \mathrm{O}_{2}$ as substrate. Briefly, cell lysate was mixed with reaction buffer. Incubation mixtures contained Tris buffer (96 mM Tris, $4.8 \mathrm{mM}$ EDTA, $960 \mu \mathrm{M} \mathrm{NaN}_{3}, \mathrm{pH} 7.6$ ) with $0.11 \%$ Triton $\mathrm{X}-100,224 \mu \mathrm{M}$ NADPH, $3.37 \mathrm{mM}$ GSH, and $78 \mathrm{mU} / \mathrm{mL}$ GR and were incubated for $10 \mathrm{~min}$ at $37{ }^{\circ} \mathrm{C}$. Ten microliters $\mathrm{H}_{2} \mathrm{O}_{2}(0.00375 \%)$ was added and the reaction was monitored for $2 \mathrm{~min}$ at $340 \mathrm{~nm}$ and $37^{\circ} \mathrm{C}$ using a microplate reader (Synergy H1) with path-length correction. Data are given as $\mathrm{mU} / \mathrm{mg}$ protein $\left(\varepsilon_{340 \mathrm{~nm}}=6.22 \mathrm{mM}^{-1} \times \mathrm{cm}^{-1}\right)$.

TXNRD activity was assessed using DTNB. Cell lysates were mixed with reaction buffer. Incubation mixtures contained $185 \mu \mathrm{L}$ phosphate buffer $\left(92.5 \mathrm{mM} \mathrm{KH}_{2} \mathrm{PO}_{4}, 1.85 \mathrm{mM}\right.$ EDTA, pH 7.4) and $15 \mu \mathrm{L}$ DTNB (3.75 mM in DMSO)). Twenty-five microliters NADPH (final concentration of $200 \mu \mathrm{M}$ in phosphate buffer) was used to start the reaction, and TNB formation was monitored at $412 \mathrm{~nm}$ for $5 \mathrm{~min}$ using a microplate reader (Synergy H1) with path-length correction. TXNRD-independent formation of TNB was determined in the absence of NADPH and was subtracted. Data are given as $\mathrm{mU} / \mathrm{mg}$ protein $\left(\varepsilon_{412 \mathrm{~nm}}=13.6 \mathrm{mM}^{-1} \times \mathrm{cm}^{-1}\right)$.

\subsection{Solid Phase Extraction of LMs}

LMs were extracted from cell culture medium as previously described [29]. Briefly, medium was mixed with a twofold amount of ice-cold methanol containing deuteriumlabeled internal standards (200 nM d8-5S-HETE, d4-LTB4, d5-LXA 4 , d5-RvD 2 , d4-PGE 2 , and $10 \mu \mathrm{M}$ d8-AA). Proteins were precipitated at $-20^{\circ} \mathrm{C}$ overnight and clear supernatant was collected after centrifugation $\left(10 \mathrm{~min}, 1200 \times g, 4^{\circ} \mathrm{C}\right)$. LMs were extracted from supernatant as previously described [59]. Briefly, the supernatant was acidified with water, $\mathrm{pH}$ 3.5, and LMs were purified by solid phase extraction (Sep-Pak ${ }^{\circledR}$ Vac 6 cc $500 \mathrm{mg} / 6 \mathrm{~mL}$ C18; Waters, Milford, CT, USA) using MilliQ water and n-hexane for washing steps. LMs were eluted with methyl formate, eluates were evaporated to dryness using nitrogen (TurboVap $\mathrm{LV}$, Biotage, Uppsala, Sweden), and LMs were resolved in $100 \mu \mathrm{L}$ methanol/water (50/50) for UPLC-MS/MS analysis [29].

\subsection{LM Analysis by UPLC-MS/MS}

Separation of LMs was performed at $50{ }^{\circ} \mathrm{C}$ on an Acquity UPLC ${ }^{\circledR}$ BEH C18 column $\left(1.7 \mu \mathrm{m}, 2.1 \times 100 \mathrm{~mm}\right.$; Waters, Eschborn, Germany) with an Acquity ${ }^{\mathrm{TM}}$ UPLC system (Waters) as described previously [29]. In brief, methanol-water-acidic acid was used as mobile phase starting at a ratio of 42:58:0.01, which was gradually changed to 86:14:0.01 over $12.5 \mathrm{~min}$ and then to 98:2:0.01 over $3 \mathrm{~min}$ using a flow rate of $0.3 \mathrm{~mL} / \mathrm{min}$. LMs were analyzed on a QTRAP 5500 ESI tandem mass spectrometer (AB Sciex, Darmstadt, Germany) which was coupled to the LC system. After electrospray ionization operated in negative mode, multiple reaction monitoring was performed in the negative ionization mode with parameters adjusted as previously described [59]. External standards were used to confirm the retention time, and calibration curves for each analyte were prepared. For quantification of LMs, analyte levels were normalized by calculating the ratio of internal standard and directly measured deuterium-labeled standards to account for loss of analytes during purification and measurement, as reported previously [60], and they were normalized to the protein content of the cells.

\subsection{Statistics}

Data are given as means $+\mathrm{SD}$ of independent experiments. The statistical analysis was performed with GraphPad Prism 8.4.3 Software (San Diego, CA, USA) using one-way, two-way or three-way analysis of variance (ANOVA) with Bonferroni's post-test. Outliers were determined by Grubbs' test, with significance level $\alpha=0.05 . p$-values $<0.05\left(^{*}\right),\left({ }^{\#}\right)$,

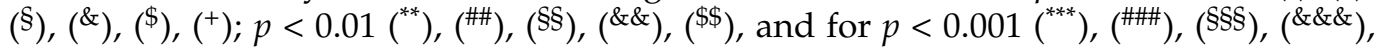


$\left({ }^{\$ \$}\right),\left({ }^{+++}\right)$were considered as statistically significant. Figures were created with GraphPad Prism 8.4.3 Software.

Supplementary Materials: The following are available online at https:/ /www.mdpi.com/article/10 .3390/ijms222011060/s1.

Author Contributions: T.W., data curation, original draft preparation, formal analysis, visualization; L.M.W., data curation, formal analysis, visualization; J.A., data curation, formal analysis, visualization; M.S., methodology, formal analysis; P.S., methodology, formal analysis, visualization; A.G., methodology, formal analysis; O.W., conceptualization, methodology, writing-review and editing; A.K., methodology, formal analysis, writing - review and editing; A.P.K., project administration, data curation, writing-review and editing, supervision, funding acquisition; S.C.K., conceptualization, data curation, investigation, project administration, writing-original draft preparation, writing-review and editing, supervision, funding acquisition. All authors have read and agreed to the published version of the manuscript.

Funding: This research was funded by the Austrian Science Fund (grant number I4968), the German Research Council (grant numbers KO4589/7-1, FOR 2558 (KI 1590/3-2)), SFB 1127 ChemBioSys 239748522), the Carl Zeiss Foundation (IMPULS), and the University of Jena (grant number AZ2.113A1_2018-02).

Data Availability Statement: The data presented in this study are available in Supplementary Materials.

Acknowledgments: We would like to thank Thomas Schneider and Michael Glei for their support concerning FACS analysis and Kristina Lossow for her support regarding the ELISA measurement. The technical assistance of Doreen Ziegenhardt and Alrun Schumann is strongly acknowledged.

Conflicts of Interest: The authors declare no conflict of interest.

\section{References}

1. Labunskyy, V.; Hatfield, D.L.; Gladyshev, V.N. Selenoproteins: Molecular Pathways and Physiological Roles. Physiol. Rev. 2014, 94, 739-777. [CrossRef] [PubMed]

2. Huang, Z.; Rose, A.H.; Hoffmann, P.R. The Role of Selenium in Inflammation and Immunity: From Molecular Mechanisms to Therapeutic Opportunities. Antioxid. Redox Signal. 2012, 16, 705-743. [CrossRef] [PubMed]

3. Avery, J.C.; Hoffmann, P.R. Selenium, Selenoproteins, and Immunity. Nutrients 2018, 10, 1203. [CrossRef] [PubMed]

4. Steinbrenner, H.; Speckmann, B.; Klotz, L.-O. Selenoproteins: Antioxidant selenoenzymes and beyond. Arch. Biochem. Biophys. 2016, 595, 113-119. [CrossRef]

5. Bertz, M.; Kühn, K.; Koeberle, S.C.; Müller, M.F.; Hoelzer, D.; Thies, K.; Deubel, S.; Thierbach, R.; Kipp, A.P. Selenoprotein $\mathrm{H}$ controls cell cycle progression and proliferation of human colorectal cancer cells. Free. Radic. Biol. Med. 2018, 127, 98-107. [CrossRef]

6. Peng, X.; Giménez-Cassina, A.; Petrus, P.; Conrad, M.; Rydén, M.; Arnér, E.S.J. Thioredoxin reductase 1 suppresses adipocyte differentiation and insulin responsiveness. Sci. Rep. 2016, 6, 28080. [CrossRef]

7. Rajalin, A.-M.; Micoogullari, M.; Sies, H.; Steinbrenner, H. Upregulation of the thioredoxin-dependent redox system during differentiation of 3T3-L1 cells to adipocytes. Biol. Chem. 2014, 395, 667-677. [CrossRef]

8. Wang, C.; Li, R.; Huang, Y.; Wang, M.; Yang, F.; Huang, D.; Wu, C.; Li, Y.; Tang, Y.; Zhang, R.; et al. Selenoprotein K modulate intracellular free $\mathrm{Ca}^{2+}$ by regulating expression of calcium homoeostasis endoplasmic reticulum protein. Biochem. Biophys. Res. Commun. 2017, 484, 734-739. [CrossRef]

9. Yan, J.; Fei, Y.; Han, Y.; Lu, S. Selenoprotein O deficiencies suppress chondrogenic differentiation of ATDC5 cells. Cell Biol. Int. 2016, 40, 1033-1040. [CrossRef]

10. Geissmann, F.; Manz, M.G.; Jung, S.; Sieweke, M.H.; Merad, M.; Ley, K. Development of Monocytes, Macrophages, and Dendritic Cells. Science 2010, 327, 656-661. [CrossRef]

11. Dall'Asta, M.; Derlindati, E.; Ardigò, D.; Zavaroni, I.; Brighenti, F.; Del Rio, D. Macrophage polarization: The answer to the diet/inflammation conundrum? Nutr. Metab. Cardiovasc. Dis. 2012, 22, 387-392. [CrossRef]

12. Gordon, S.; Taylor, P. Monocyte and macrophage heterogeneity. Nat. Rev. Immunol. 2005, 5, 953-964. [CrossRef]

13. Dorrington, M.G.; Fraser, I.D.C.; Dorrington, M.G.; Fraser, I.D.C. NF-кB Signaling in Macrophages: Dynamics, Crosstalk, and Signal Integration. Front. Immunol. 2019, 10, 705. [CrossRef]

14. Saha, S.; Buttari, B.; Panieri, E.; Profumo, E.; Saso, L. An Overview of Nrf2 Signaling Pathway and Its Role in Inflammation. Molecules 2020, 25, 5474. [CrossRef]

15. He, F.; Ru, X.; Wen, T. NRF2, a Transcription Factor for Stress Response and Beyond. Int. J. Mol. Sci. 2020, 21, 4777. [CrossRef]

16. Michalke, B. Selenium; Springer: Berlin/Heidelberg, Germany, 2018. [CrossRef] 
17. Schomburg, L.; Schweizer, U. Hierarchical regulation of selenoprotein expression and sex-specific effects of selenium. Biochim. Biophys. Acta 2009, 1790, 1453-1462. [CrossRef]

18. Papp, L.V.; Lu, J.; Holmgren, A.; Khanna, K.K. From Selenium to Selenoproteins: Synthesis, Identity, and Their Role in Human Health. Antioxid. Redox Signal. 2007, 9, 775-806. [CrossRef]

19. Reeves, M.A.; Hoffmann, P.R. The human selenoproteome: Recent insights into functions and regulation. Cell. Mol. Life Sci. 2009, 66, 2457-2478. [CrossRef]

20. Auwerx, J. The human leukemia cell line, THP-1: A multifacetted model for the study of monocyte-macrophage differentiation. Cell. Mol. Life Sci. 1991, 47, 22-31. [CrossRef]

21. Daigneault, M.; Preston, J.; Marriott, H.; Whyte, M.K.B.; Dockrell, D.H. The Identification of Markers of Macrophage Differentiation in PMA-Stimulated THP-1 Cells and Monocyte-Derived Macrophages. PLoS ONE 2010, 5, e8668. [CrossRef]

22. Lund, M.E.; To, J.; O'Brien, B.A.; Donnelly, S. The choice of phorbol 12-myristate 13-acetate differentiation protocol influences the response of THP-1 macrophages to a pro-inflammatory stimulus. J. Immunol. Methods 2016, 430, 64-70. [CrossRef]

23. Maeß, M.B.; Wittig, B.; Cignarella, A.; Lorkowski, S. Reduced PMA enhances the responsiveness of transfected THP-1 macrophages to polarizing stimuli. J. Immunol. Methods 2014, 402, 76-81. [CrossRef]

24. Li, T.; Yang, W.; Li, M.; Byun, D.-S.; Tong, C.; Nasser, S.; Zhuang, M.; Arango, D.; Mariadason, J.M.; Augenlicht, L.H. Expression of selenium-binding protein 1 characterizes intestinal cell maturation and predicts survival for patients with colorectal cancer. Mol. Nutr. Food Res. 2008, 52, 1289-1299. [CrossRef]

25. Steinbrenner, H.; Micoogullari, M.; Hoang, N.A.; Bergheim, I.; Klotz, L.-O.; Sies, H. Selenium-binding protein 1 (SELENBP1) is a marker of mature adipocytes. Redox Biol. 2018, 20, 489-495. [CrossRef]

26. Chen, G.; Wang, H.; Miller, C.T.; Thomas, D.G.; Gharib, T.G.; E Misek, D.; Giordano, T.J.; Orringer, M.B.; Hanash, S.M.; Beer, D.G. Reduced selenium-binding protein 1 expression is associated with poor outcome in lung adenocarcinomas. J. Pathol. 2004, 202, 321-329. [CrossRef]

27. Wang, N.; Chen, Y.; Yang, X.; Jiang, Y. Selenium-binding protein 1 is associated with the degree of colorectal cancer differentiation and is regulated by histone modification. Oncol. Rep. 2014, 31, 2506-2514. [CrossRef]

28. Sivandzade, F.; Prasad, S.; Bhalerao, A.; Cucullo, L. NRF2 and NF-қB interplay in cerebrovascular and neurodegenerative disorders: Molecular mechanisms and possible therapeutic approaches. Redox Biol. 2018, 21, 101059. [CrossRef]

29. Koeberle, S.C.; Gollowitzer, A.; Laoukili, J.; Kranenburg, O.; Werz, O.; Koeberle, A.; Kipp, A.P. Distinct and overlapping functions of glutathione peroxidases 1 and 2 in limiting NF- $\mathrm{kB}$-driven inflammation through redox-active mechanisms. Redox Biol. 2019, 28, 101388. [CrossRef]

30. Vunta, H.; Davis, F.; Palempalli, U.D.; Bhat, D.; Arner, R.J.; Thompson, J.T.; Peterson, D.G.; Reddy, C.C.; Prabhu, K.S. The Anti-inflammatory Effects of Selenium Are Mediated through 15-Deoxy- $\Delta 12,14$-prostaglandin J2 in Macrophages. J. Biol. Chem. 2007, 282, 17964-17973. [CrossRef]

31. Wang, H.; Bi, C.; Wang, Y.; Sun, J.; Meng, X.; Li, J. Selenium ameliorates Staphylococcus aureus-induced inflammation in bovine mammary epithelial cells by inhibiting activation of TLR2, NF-кB and MAPK signaling pathways. BMC Vet. Res. 2018, 14, 197. [CrossRef]

32. Hiller, F.; Oldorff, L.; Besselt, K.; Kipp, A.P. Differential Acute Effects of Selenomethionine and Sodium Selenite on the Severity of Colitis. Nutrients 2015, 7, 2687-2706. [CrossRef] [PubMed]

33. Liu, K.; Ding, T.; Fang, L.; Cui, L.; Li, J.; Meng, X.; Zhu, G.; Qian, C.; Wang, H.; Li, J. Organic Selenium Ameliorates Staphylococcus aureus-Induced Mastitis in Rats by Inhibiting the Activation of NF-kB and MAPK Signaling Pathways. Front. Vet. Sci. 2020, 7, 443. [CrossRef] [PubMed]

34. Barrett, C.W.; Reddy, V.K.; Short, S.; Motley, A.K.; Lintel, M.K.; Bradley, A.M.; Freeman, T.; Vallance, J.; Ning, W.; Parang, B.; et al. Selenoprotein P influences colitis-induced tumorigenesis by mediating stemness and oxidative damage. J. Clin. Investig. 2015, 125, 2646-2660. [CrossRef] [PubMed]

35. A Carlson, B.; Yoo, M.-H.; Sano, Y.; Sengupta, A.; Kim, J.Y.; Irons, R.; Gladyshev, V.N.; Hatfield, D.L.; Park, J.M. Selenoproteins regulate macrophage invasiveness and extracellular matrix-related gene expression. BMC Immunol. 2009, 10, 57. [CrossRef]

36. Nelson, S.M.; Lei, X.; Prabhu, K.S. Selenium Levels Affect the IL-4-Induced Expression of Alternative Activation Markers in Murine Macrophages. J. Nutr. 2011, 141, 1754-1761. [CrossRef]

37. Norton, R.L.; Fredericks, G.J.; Huang, Z.; Fay, J.D.; Hoffmann, F.W.; Hoffmann, P.R. Selenoprotein K regulation of palmitoylation and calpain cleavage of ASAP2 is required for efficient Fc $\gamma$ R-mediated phagocytosis. J. Leukoc. Biol. 2016, 101, 439-448. [CrossRef]

38. Verma, S.; Hoffmann, F.W.; Kumar, M.; Huang, Z.; Roe, K.; Nguyen-Wu, E.; Hashimoto, A.S.; Hoffmann, P.R. Selenoprotein K Knockout Mice Exhibit Deficient Calcium Flux in Immune Cells and Impaired Immune Responses. J. Immunol. 2011, 186, 2127-2137. [CrossRef]

39. Brigelius-Flohé, R.; Friedrichs, B.; Maurer, S.; Schultz, M.; Streicher, R. Interleukin-1-induced nuclear factor $к B$ activation is inhibited by overexpression of phospholipid hydroperoxide glutathione peroxidase in a human endothelial cell line. Biochem. J. 1997, 328, 199-203. [CrossRef]

40. Bi, C.-L.; Wang, H.; Wang, Y.-J.; Sun, J.; Dong, J.-S.; Meng, X.; Li, J.-J. Selenium inhibits Staphylococcus aureus-induced inflammation by suppressing the activation of the NF- $\mathrm{KB}$ and MAPK signalling pathways in RAW264.7 macrophages. Eur. J. Pharmacol. 2016, 780, 159-165. [CrossRef] 
41. Mao, H.; Zhao, Y.; Li, H.; Lei, L. Ferroptosis as an emerging target in inflammatory diseases. Prog. Biophys. Mol. Biol. 2020, 155, 20-28. [CrossRef]

42. Mattmiller, S.A.; Carlson, B.A.; Gandy, J.C.; Sordillo, L.M. Reduced macrophage selenoprotein expression alters oxidized lipid metabolite biosynthesis from arachidonic and linoleic acid. J. Nutr. Biochem. 2014, 25, 647-654. [CrossRef]

43. Zamamiri-Davis, F.; Lu, Y.; Thompson, J.T.; Prabhu, K.; Reddy, P.V.; Sordillo, L.M.; Reddy, C. Nuclear factor-kB mediates over-expression of cyclooxygenase-2 during activation of RAW 264.7 macrophages in selenium deficiency. Free. Radic. Biol. Med. 2002, 32, 890-897. [CrossRef]

44. Wan, J.M.-F.; Lee, C.-Y.J. Immunoregulatory and Antioxidant Performance of $\alpha$-Tocopherol and Selenium on Human Lymphocytes. Biol. Trace Elem. Res. 2002, 86, 123-136. [CrossRef]

45. Spallholz, J.E. Free radical generation by selenium compounds and their prooxidant toxicity. Biomed. Environ. Sci. 1997, 10, 260-270.

46. Stewart, M.S.; E Spallholz, J.; Neldner, K.H.; Pence, B.C. Selenium compounds have disparate abilities to impose oxidative stress and induce apoptosis. Free. Radic. Biol. Med. 1998, 26, 42-48. [CrossRef]

47. Karwaciak, I.; Gorzkiewicz, M.; Bartosz, G.; Pulaski, L. TLR2 activation induces antioxidant defence in human monocytemacrophage cell line models. Oncotarget 2017, 8, 54243-54264. [CrossRef]

48. Müller, M.; Banning, A.; Brigelius-Flohé, R.; Kipp, A. Nrf2 target genes are induced under marginal selenium-deficiency. Genes Nutr. 2010, 5, 297-307. [CrossRef]

49. Chang, L.-C.; Chiang, S.-K.; Chen, S.-E.; Yu, Y.-L.; Chou, R.-H.; Chang, W.-C. Heme oxygenase-1 mediates BAY 11-7085 induced ferroptosis. Cancer Lett. 2018, 416, 124-137. [CrossRef]

50. Iida, Y.; Okamoto-Katsuyama, M.; Maruoka, S.; Mizumura, K.; Shimizu, T.; Shikano, S.; Hikichi, M.; Takahashi, M.; Tsuya, K.; Okamoto, S.; et al. Effective ferroptotic small-cell lung cancer cell death from SLC7A11 inhibition by sulforaphane. Oncol. Lett. 2020, 21, 71. [CrossRef]

51. Steinbrenner, H.; Al-Quraishy, S.; Dkhil, M.; Wunderlich, F.; Sies, H. Dietary Selenium in Adjuvant Therapy of Viral and Bacterial Infections. Adv. Nutr. 2015, 6, 73-82. [CrossRef]

52. Zhang, J.; Saad, R.; Taylor, E.W.; Rayman, M.P. Selenium and selenoproteins in viral infection with potential relevance to COVID-19. Redox Biol. 2020, 37, 101715. [CrossRef]

53. Diwakar, B.T.; Korwar, A.M.; Paulson, R.F.; Prabhu, K.S. The Regulation of Pathways of Inflammation and Resolution in Immune Cells and Cancer Stem Cells by Selenium. Adv. Cancer Res. 2017, 136, 153-172. [CrossRef]

54. Kaur, S.; Harjai, K.; Chhibber, S. In Vivo Assessment of Phage and Linezolid Based Implant Coatings for Treatment of Methicillin Resistant S. aureus (MRSA) Mediated Orthopaedic Device Related Infections. PLoS ONE 2016, 11, e0157626. [CrossRef]

55. Nettleford, S.K.; Zhao, L.; Qian, F.; Herold, M.; Arner, B.; Desai, D.; Amin, S.; Xiong, N.; Singh, V.; Carlson, B.A.; et al. The Essential Role of Selenoproteins in the Resolution of Citrobacter rodentium-Induced Intestinal Inflammation. Front. Nutr. 2020, 7, 96. [CrossRef]

56. Schwarz, M.; Lossow, K.; Schirl, K.; Hackler, J.; Renko, K.; Kopp, J.F.; Schwerdtle, T.; Schomburg, L.; Kipp, A.P. Copper interferes with selenoprotein synthesis and activity. Redox Biol. 2020, 37, 101746. [CrossRef]

57. Winther, J.R.; Thorpe, C. Quantification of thiols and disulfides. Biochim. Biophys. Acta (BBA)—Gen. Subj. 2013, 1840, 838-846. [CrossRef]

58. Prochaska, H.J.; Santamaria, A.B. Direct measurement of NAD(P)H:quinone reductase from cells cultured in microtiter wells: A screening assay for anticarcinogenic enzyme inducers. Anal. Biochem. 1988, 169, 328-336. [CrossRef]

59. Werz, O.; Gerstmeier, J.; Libreros, S.; De La Rosa, X.; Werner, M.; Norris, P.; Chiang, N.; Serhan, C.N. Human macrophages differentially produce specific resolvin or leukotriene signals that depend on bacterial pathogenicity. Nat. Commun. 2018, 9, 59. [CrossRef]

60. Schädel, P.; Troisi, F.; Czapka, A.; Gebert, N.; Pace, S.; Ori, A.; Werz, O. Aging drives organ-specific alterations of the inflammatory microenvironment guided by immunomodulatory mediators in mice. FASEB J. 2021, 35, e21558. [CrossRef] 